\title{
Article \\ Insight into Geochemical Significance of NO Compounds in Lacustrine Shale Source Rocks by FT-ICR MS
}

\author{
Hong $\mathrm{Ji}^{1,2, *}$, Sumei $\mathrm{Li}^{2}{ }^{2 *}$, Hongan Zhang ${ }^{3}$, Xiongqi Pang ${ }^{2}$ and Tianwu $\mathrm{Xu}^{3}$ \\ 1 School of Science, Guangdong University of Petrochemical Technology, Maoming 525000, China \\ 2 State Key Laboratory of Petroleum Resources and Prospecting, China University of Petroleum, \\ Beijing 102249, China; pangxq@cup.edu.cn \\ 3 Sinopec Zhongyuan Oilfield Company, Puyang 457001, China; zha@siopec.com (H.Z.); \\ xtw_siopec@163.com (T.X.) \\ * Correspondence: jihong@gdupt.edu.com (H.J.); smli8888@yahoo.com.cn (S.L.)
}

check for updates

Citation: Ji, H.; Li, S.; Zhang, H.; Pang, X.; Xu, T. Insight into Geochemical Significance of NO Compounds in Lacustrine Shale Source Rocks by FT-ICR MS. Energies 2022, 15, 1805. https://doi.org/ 10.3390/en15051805

Academic Editors: Reza Rezaee, Xixin Wang, Luxing Dou and Yuming Liu

Received: 27 December 2021 Accepted: 22 February 2022 Published: 28 February 2022

Publisher's Note: MDPI stays neutral with regard to jurisdictional claims in published maps and institutional affiliations.

Copyright: () 2022 by the authors Licensee MDPI, Basel, Switzerland. This article is an open access article distributed under the terms and conditions of the Creative Commons Attribution (CC BY) license (https:// creativecommons.org/licenses/by/ $4.0 /)$.

\begin{abstract}
Nitrogen and oxygen (NO) compounds are important compositions in shale source rocks, and they carry an abundance of geochemical information for hydrocarbon generation. Due to technical limitations, the significance of $\mathrm{NO}$ compounds has not been paid enough attention. In this paper, the NO compounds from shale rocks of the Dongpu Depression are analyzed to explore the compositional characteristics and geochemical significance of using geological and organic geochemical ways of rock-eval, gas chromatography-mass spectrometry (GC/MS), and Fourier transform ion cyclotron resonance mass spectrometry (FT-ICR MS). The results show that shale rocks are rich in $\mathrm{NO}$ compounds, with twelve types of compounds that were detected: $\mathrm{N}_{1}, \mathrm{~N}_{1} \mathrm{O}_{1}, \mathrm{~N}_{1} \mathrm{O}_{2}$, $\mathrm{N}_{1} \mathrm{O}_{3}, \mathrm{~N}_{1} \mathrm{~S}_{1}, \mathrm{~N}_{1} \mathrm{~S}_{2}, \mathrm{~N}_{2} \mathrm{O}_{1}, \mathrm{O}_{1}, \mathrm{O}_{2}, \mathrm{O}_{3}, \mathrm{O}_{3} \mathrm{~S}_{1}$, and $\mathrm{O}_{4}$. Of these compounds, $\mathrm{O}_{2}$ and $\mathrm{O}_{3}$ predominated, followed by $\mathrm{N}_{1}$ and $\mathrm{N}_{1} \mathrm{O}_{1}$. Of the $\mathrm{N}_{1}$ species, the most abundant classes are DBE of $9,12,15$, and 18 , which changed with maturity. Of the $\mathrm{O}_{2}$ species, compounds of DBE of 1 (fatty acids) are the predominant class. Classes of DBE 5 and 6 in the $\mathrm{O}_{2}$ species are naphthenic acids with special biological skeleton structures, which are usually appear in immature and low-mature oils. $\mathrm{N}_{1}$, $\mathrm{O}_{2}$, and $\mathrm{N}_{1} \mathrm{O}_{1}$ compounds are affected by their maturity and they often run to polarization with enhanced DBE species and a shorter carbon chain as their maturity increases. The parameters of $\mathrm{DBE}_{18-25} / \mathrm{DBE}_{9-18}-\mathrm{N}_{1}$ and $\mathrm{DBE}_{12-20} / \mathrm{DBE}_{5-12}-\mathrm{O}_{2}$ increase with the increase of buried depth and maturity. The NO compounds that were revealed by FT-ICR MS may have a promising application in distinguishing between the different depositional environments. Source rocks of saline lacustrine are rich in $\mathrm{O}_{2}$ and $\mathrm{N}_{1} \mathrm{O}_{1}$, but less $\mathrm{N}_{1}$ and $\mathrm{O}_{1}$ compounds. The research results are of vital importance for expanding the application of the NO molecular compounds in petroleum exploration.
\end{abstract}

Keywords: source rocks; nitrogen and oxygen compounds; FT-ICR MS; geochemical significance; Dongpu depression

\section{Introduction}

Nitrogen $(\mathrm{N})$ and oxygen $(\mathrm{O})$ compounds are important heteroatomic polar compounds in shale oil. Understanding the composition and distribution of NO compounds in shale rocks is of vital importance for studying the physical properties of shale rocks, as well as the mobility and the source of shale oil [1-3]. For example, the generation type and abundance of polar compounds (including organic acids) in NO compounds directly affects the wettability and occurrence state of shale oil and organic acid compounds that directly participate in improving the microscopic pore structure of the rock minerals $[4,5]$, which are the decisive factors for shale oil mobility. Studies on hydrocarbons in shale oil are commonly reported [6,7] while research on non-hydrocarbons (NO compounds) in shale oil is rare. NO compounds also carry abundant geochemical information for hydrocarbon exploration, and the application of low molecular weight $\mathrm{NO}$ compounds in oil exploration is 
under constant research. The distribution and composition characteristics of neutral oxygen compounds can be used for the identification of crude oil genesis and biodegradation [8,9], and pyrrole nitrogen compounds can be used for crude oil maturity [10] and hydrocarbon migration indicators [11-13]. Although experts in the petroleum field have executed a variety of exploratory work on the exploration, evaluation, and resource prediction of shale oils in recent years [14], further research is still needed. For example, the description of the physical properties and components of crude oil still that are confined to macroscopic characterization such as the density, viscosity, organic element composition, and group composition. The NO compounds are high polar compounds that conventional approaches such as gas chromatography-mass spectrometer (GC-MS) cannot obtain precise and higher molecular $(>400 \mathrm{~m} / \mathrm{z})$ information, which restricts the application of NO compounds in exploration and development. Fourier transform ion cyclotron resonance mass spectrometry (FT-ICR MS) is a new technique for detecting petroleum components in details within the scope of low to high molecular $(<m / z$ 800). The FT-ICR MS combined with electrospray ionization source (ESI) is adequate for detecting the molecular composition of NO polar heteroatom compounds in complex petroleum matrices due to its ultra-high mass spectrometry resolution, high mass accuracy, and selective ionization for polar compounds.

Hydrocarbon displays are frequently shown in the shale rocks of the third member of the Shahejie Formation in the northern part of the Dongpu Depression. The shale rocks of the third member of the Shahejie Formation in Well Pushen 18-1 obtained a daily oil production of $420 \mathrm{t}$ oil flow, indicating that the Dongpu Depression is of great potential for shale oil [15]. Previous studies have also reported that shale oil is rich in the Dongpu Depression [16,17]. Some research on the hydrocarbon compounds that were generated from the mud shale in the Dongpu Depression has been carried out $[18,19]$. However, limited by the analysis and techniques, the compositional characteristics of NO non-hydrocarbon compounds in the shale rocks are still not available. Taking shale rocks of the northern part of the Dongpu Depression as examples, this study uses rock-eval, GC-MS, and FT-ICR MS methods to reveal the detailed compositional characteristics of hydrocarbons and non-hydrocarbons, especially the NO compounds, of the mud shale and explore their geochemical significance in petroleum exploration. The results of this work can be used for other basins with similar geologic backgrounds, providing both regional and comprehensive expectations for the findings of this study.

\section{Geologic Setting}

The Dongpu Depression is a Cenozoic salt-bearing basin with a north-northeast strike in the southeast region of the Linqing Depression in the Bohai Bay Basin with an area of $5300 \mathrm{~km}^{2}$ (Figure 1a-c). It is generally bounded by the Lanliao fault to the east, and the Luxi uplift to the west (Figure 1a). The faults divided it into several structural belts that are the western slope belt, the western depression, the central uplift zone, the eastern depression zone, and the eastern steep slope zone from west to east (Figure 1a). The Dongpu Depression is a rift basin that is dominated by saline lacustrine deposits of the Paleogene. The basement of the Dongpu Depression is made up of the Lower Paleozoic Ordovician, Cambrian, and Upper Paleozoic Carboniferous-Permian (Figure 1d). The Paleogene Shahejie Formation and the Lower Paleozoic Permian are the primary oiland gas-bearing source rocks in the Dongpu Depression, respectively. The sedimentary basin has undergone two stages of Paleogene rifting and Neogene depression, and the maximum thickness of the Cenozoic is more than $9000 \mathrm{~m}$, of which the thickness of the Paleogene is more than $6000 \mathrm{~m}$. There are two relatively obvious water ingressionregression sedimentary cycles. One is from the fourth member of the Shahejie Formation to the lower part of the second member of the Shahejie Formation $\left(\mathrm{Es}_{4}-\mathrm{Es}_{2}{ }^{\mathrm{L}}\right)$, and the other one is from the upper member of the second member of the Shahejie Formation to the Dongying Formation $\left(\mathrm{Es}_{2}{ }_{2} \mathrm{~L}-\mathrm{Ed}\right)$. The third member of the Shahejie Formation $\left(\mathrm{Es}_{3}\right)$ is the heyday of the development of saline lacustrine basins, and its various sedimentary processes are very active. It is the main stage for the accumulation of hydrocarbon source rocks, salt rocks, and 
favorable reservoirs. The shale of the third member of the Shahejie Formation $\left(\mathrm{Es}_{3}\right)$ is thick and abundant in organic matter and shows great shale oil resource potential [20]. Many oil and gas fields, such as Wenliu, Wenmingzhai, Weicheng, Pucheng, and Guyunji, have been discovered. The proven oil and natural gas reserves are $12.37 \times 10^{8} \mathrm{t}$ and $3.675 \times 10^{8} \mathrm{~m}^{3}$, respectively. The oil and gas are mainly distributed in the second and third members of the Shahejie Formation in the northern saline lacustrine facies regions [21]. There are four suits of thick gypsum salt rocks in the northern part of the depression. The source rocks and gypsum salt rocks, both of which are closely correlated to the generation of the petroleum in the area, are interbedded vertically and superimposed on the plane.
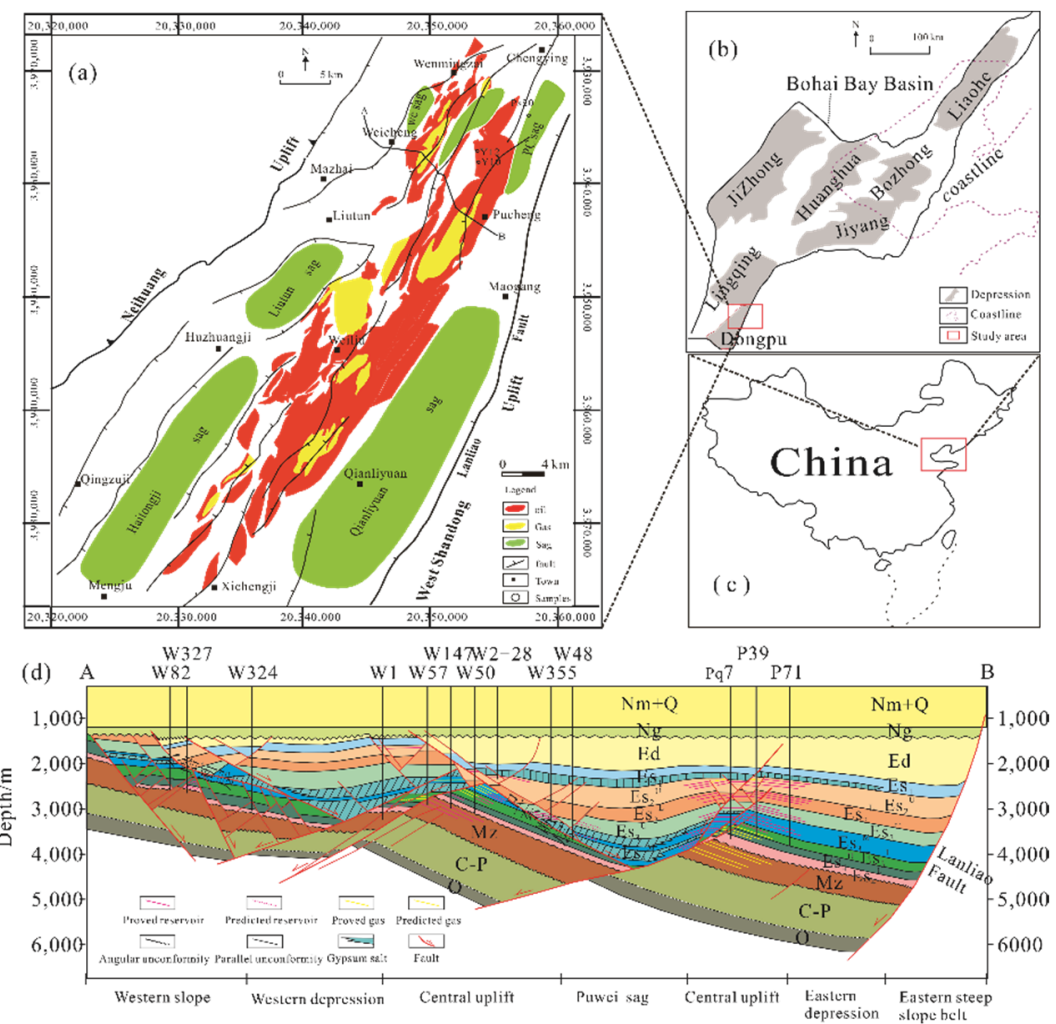

Figure 1. Location of the study area (a) on the background of Bohai Bay Basin (b) of China map (c), and sedimentary profile marked on the map with tectonic line A-B (d) according to [18].

\section{Materials and Methods}

\subsection{Samples}

A total of eight shale source rocks of the third member of Shahejie Formation $\left(\mathrm{Es}_{3}\right)$ of the saline lacustrine facies in the north of the Dongpu Depression were selected, and Rock-Eval pyrolysis and total organic carbon (TOC) measurements were conducted in the State Key Laboratory of China University of Petroleum (Beijing). Gas chromatographymass spectrometry (GC-MS) and electrospray ionization Fourier transform ion cyclotron resonance mass spectrometry (ESI FT-ICR MS) were performed on the source rocks in the State Key Laboratory of Heavy Oil Processing, China.

\subsection{Rock-Eval Pyrolysis and TOC}

The core sample to be analyzed were cleaned and then crushed. About $100 \mathrm{mg}$ of the rock sample was put into a pyrolysis furnace that was equipped with a flame ionization detector (FID) and heated to $300^{\circ} \mathrm{C}$ for $3 \mathrm{~min}$, then heated to $600{ }^{\circ} \mathrm{C}$ at a heating rate of $25^{\circ} \mathrm{C} / \mathrm{min}$ to receive $S_{1}$ and $S_{2}$ hydrocarbon peaks, respectively. The source rocks were performed by LECO CS-230 to regulate the TOC content in the State Key Laboratory of China University of Petroleum (Beijing). The inorganic carbon was removed from the rock with hydrochloric acid, and the organic matter was then burned at a high temperature until 
it was fully oxidized and decomposed. Finally, the combustion products were measured and then converted to the composition of organic elements. The processes for the TOC measurement and rock pyrolysis analysis followed the China GB/T 19145-2003 and China GB/T 215-2003 standards, respectively.

\subsection{GC-MS Analysis}

The extracted organic matter was submitted for GC/MS analysis in the State Key Laboratory of China University of Petroleum (Beijing). GC-MS analysis adopts Agilent 6890 chromatography, equipped with an Agilent 5979 mass detector. The saturated hydrocarbon and aromatic hydrocarbon fractionation instruments are $30 \mathrm{~m} \times 0.25 \mathrm{~mm} \times 0.25 \mu \mathrm{m}$ and $60 \mathrm{~m} \times 0.25 \mathrm{~mm} \times 0.25 \mu \mathrm{m}$ HP-5MS elastic fused silica capillary column.

\subsection{FT-ICR MS Analysis}

The FT-ICR MS analysis was performed in the State Key Laboratory of Heavy Oil Processing, China. The analysis was carried out on a Bruker Apex-Ultra FT-ICR mass spectrometry that was equipped with a 9.4-T superconducting magnet. The sample solution was dissolved by a syringe pump using an Apollo II electrospray source (ESI) at a concentration of $180 \mu \mathrm{L} / \mathrm{h}$. The negative mode of ESI was adopted in the analysis. Under the working conditions of general negative ion formation, the spray shielding voltage was $4000 \mathrm{~V}$. The introduction voltage of the capillary column is $4500 \mathrm{~V}$ and the end voltage was $320 \mathrm{~V}$. The ions were accumulated for $0.1 \mathrm{~s}$ in a hexapole electrode with a direct current (DC) voltage of $2.4 \mathrm{~V}$ and a radio frequency (RF) amplitude of $400 \mathrm{~V}$ p-p (volts peak-peak). The optimized mass for Q1 was $m / z$ 300. The ion accumulation time was $0.4 \mathrm{~s}$ in an argon-filled hexapole collision cell at $5 \mathrm{MHz}$ and an RF amplitude of $400 \mathrm{~V} \mathrm{p}$-p. The extraction period of the ions from the hexapole to the ICR cells was $1.2 \mathrm{~s}$. The RF excitation decayed at $11.75 \mathrm{~dB}$ for exciting the ions in the $m / z$ 200-900 Da range. A dataset of $4 \mathrm{M}$ words was obtained. A total of 64 scans were added to improve the signal-noise ratio. A square-sine bell multiplication was done, followed by one zero padding, followed by fast Fourier transform and magnitude calculation. The signal-to-noise $(\mathrm{S} / \mathrm{N})$ threshold that was used was $\geq 6$, and the calibration error was $<1 \mathrm{ppm}$. In the negative electrospray ionization (ESI) mode, only negative singly charged compounds are formed; therefore, in this study, $\mathrm{m} / \mathrm{z}$ and mass are synonymous. In the subsequent analysis, different nitrogen-containing compounds were classified according to double bond equivalent weight (DBE). For a given compound, $\mathrm{CcHhNnOoSs}$, its DBE was calculated as: $\mathrm{DBE}=\mathrm{c}-0.5 \mathrm{~h}+0.5 \mathrm{n}+1 \mathrm{DBE}$ is a measure of the degree of unsaturation of a molecule and indicates the number of its double bonds and rings [22].

\section{Results}

4.1. Conventional Characteristics of the Source Rocks

\subsubsection{Source Rock Evaluation}

The organic carbon and pyrolysis of the mud shale source rocks from the middle and lower sections of the third member of the Shahejie Formation were analyzed, respectively. The TOC of the analyzed source rocks was $0.42-3.90 \%$, with an average of 1.81 wt.\% (Figure 2, Table 1). The hydrocarbon generation potential index $\left(S_{1}+S_{2}\right)$ was scattered from 1.13-32.60, with mean value of $12.08 \mathrm{mg} \mathrm{HC} / \mathrm{g}$ (Figure 2, Table 1). According to the organic matter evaluation standard of the source rock in the lacustrine basin $[23,24]$, the samples A1, B1-B3, and C belonged to good to high-quality source rocks; D1 and D2 source rocks were of medium quality; and the C1 source rocks were of relatively poor quality (Figure 2, Table 1). 


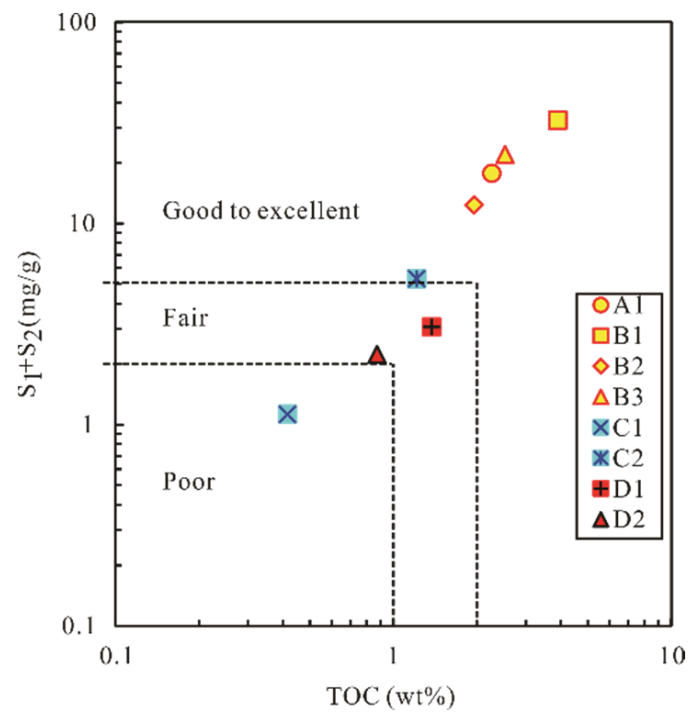

Figure 2. Correlation diagram of the organic carbon and hydrocarbon generation potential of source rocks in the middle and lower members of $\mathrm{Es}_{3}$ in the Dongpu Depression.

Table 1. Conventional geochemical parameters for the source rocks and oil sands that were analyzed.

\begin{tabular}{|c|c|c|c|c|c|c|c|c|}
\hline Well & WQ1 & W18-5 & W18-5 & W18-5 & W79-8 & W79-8 & PS20 & PS20 \\
\hline $\begin{array}{l}\text { Depth }(\mathrm{m}) \\
\text { Strata }\end{array}$ & $\begin{array}{c}2588.39 \\
\mathrm{Es}_{3} \mathrm{M}\end{array}$ & $\begin{array}{c}2661.55 \\
\mathrm{Es}_{3}{ }^{\mathrm{M}}\end{array}$ & $\begin{array}{c}2712.82 \\
\mathrm{Es}_{3} \mathrm{~L}\end{array}$ & $\begin{array}{c}2933.49 \\
\mathrm{Es}_{3} \mathrm{~L}\end{array}$ & $\begin{array}{c}3368.01 \\
\mathrm{Es}_{3} \mathrm{~L}\end{array}$ & $\begin{array}{c}3467.5 \\
\mathrm{Es}_{3} \mathrm{~L}\end{array}$ & $\begin{array}{c}4440.27 \\
\mathrm{Es}_{3} \mathrm{M}\end{array}$ & $\begin{array}{c}4555.28 \\
\mathrm{Es}_{3} \mathrm{~L}\end{array}$ \\
\hline Lithology & $\begin{array}{l}\text { Brown-Dark } \\
\text { Oil Shale }\end{array}$ & $\begin{array}{l}\text { Brown-Dark } \\
\text { Oil Shale }\end{array}$ & $\begin{array}{l}\text { Brown-Dark } \\
\text { Oil Shale }\end{array}$ & $\begin{array}{l}\text { Brown-Dark } \\
\text { Oil Shale }\end{array}$ & $\begin{array}{l}\text { Brown-Dark } \\
\text { Oil Shale }\end{array}$ & $\begin{array}{l}\text { Grey-Dark } \\
\text { Oil Shale }\end{array}$ & $\begin{array}{l}\text { Grey-Dark } \\
\text { Mudstone }\end{array}$ & $\begin{array}{l}\text { Grey-Dark } \\
\text { Mudstone }\end{array}$ \\
\hline $\begin{array}{l}\text { Lab. No. } \\
\text { TOC (\%) }\end{array}$ & $\begin{array}{c}\text { A1 } \\
2.26\end{array}$ & $\begin{array}{c}\text { B1 } \\
3.90\end{array}$ & $\begin{array}{c}\text { B2 } \\
1.95\end{array}$ & $\begin{array}{c}\text { B3 } \\
2.52\end{array}$ & $\begin{array}{c}\mathrm{C} 1 \\
0.42\end{array}$ & $\begin{array}{c}\text { C2 } \\
1.21\end{array}$ & $\begin{array}{c}\text { D1 } \\
1.37\end{array}$ & $\begin{array}{c}\mathrm{D} 2 \\
0.87\end{array}$ \\
\hline $\begin{array}{l}\mathrm{S}_{1}+\mathrm{S}_{2} \\
(\mathrm{mg} / \mathrm{g})\end{array}$ & 17.78 & 32.60 & 12.39 & 22.06 & 1.13 & 5.33 & 3.07 & 2.24 \\
\hline $\mathrm{T}_{\max }\left({ }^{\circ} \mathrm{C}\right)$ & 432.00 & 429.00 & 447.00 & 437.00 & 426.00 & 448.00 & 454.50 & 451.00 \\
\hline $\mathrm{HI}(\mathrm{mg} / \mathrm{g})$ & 742.92 & 721.03 & 604.10 & 793.65 & 153.85 & 377.69 & 188.69 & 165.14 \\
\hline O.M.Type & I & I & I & I & $\mathrm{II}_{\mathrm{B}}$ & $\mathrm{II}_{\mathrm{A}}$ & I & $\mathrm{II}_{\mathrm{A}}$ \\
\hline CPI & 0.76 & 0.90 & 0.92 & 1.18 & 0.94 & 1.06 & 0.95 & l \\
\hline OEP & 1.09 & 0.72 & 0.92 & 1.12 & 0.85 & 1.02 & 0.97 & / \\
\hline $\mathrm{Pr} / \mathrm{Ph}$ & 0.07 & 0.21 & 0.36 & 0.48 & 0.25 & 0.30 & 0.52 & 0.83 \\
\hline $\operatorname{Pr} / \mathrm{nC}_{17}$ & 0.29 & 0.76 & 0.79 & 1.20 & 0.57 & 0.54 & 0.40 & 0.57 \\
\hline $\mathrm{Ph} / \mathrm{nC}_{18}$ & 4.07 & 2.60 & 1.53 & 1.91 & 1.77 & 1.22 & 0.67 & 0.42 \\
\hline $\mathrm{C}_{21-22} / \mathrm{C}_{28-29}$ & 0.56 & 0.72 & 0.79 & 0.39 & 1.11 & 1.07 & 1.54 & / \\
\hline$\sum \mathrm{nC}_{21-} / \sum \mathrm{nC}_{22+}$ & 0.85 & 0.54 & 0.50 & 0.28 & 0.73 & 0.38 & 0.74 & 1 \\
\hline $\mathrm{Dia} / \mathrm{reg}$ & 0.08 & 0.14 & 0.14 & 0.15 & 0.09 & 0.31 & 0.82 & 1.20 \\
\hline $\mathrm{C}_{27} / \mathrm{C}_{29} \mathrm{~S}$ & 0.91 & 1.24 & 0.86 & 0.99 & 0.51 & 0.95 & 1.96 & \\
\hline $20 \mathrm{~S}$ & 0.17 & 0.36 & 0.26 & 0.24 & 0.27 & 0.43 & 0.47 & 0.57 \\
\hline$\alpha \beta \beta$ & 0.23 & 0.39 & 0.25 & 0.22 & 0.23 & 0.48 & 0.58 & 0.57 \\
\hline $\mathrm{Ts} /(\mathrm{Ts}+\mathrm{Tm})$ & 0.18 & 0.24 & 0.23 & 0.27 & 0.25 & 0.34 & 0.51 & 0.90 \\
\hline $\mathrm{G} / \mathrm{C}_{30} \mathrm{H}$ & 0.24 & 0.80 & 0.58 & 0.48 & 0.43 & 2.52 & 3.14 & / \\
\hline $\mathrm{C}_{35} \mathrm{H} / \mathrm{C}_{34} \mathrm{H}$ & 1.10 & 1.53 & 1.54 & 0.99 & 0.62 & 0.83 & 1.52 & 3.11 \\
\hline DBTs $(\%)$ & 9.34 & 35.34 & 16.12 & 2.89 & 5.72 & 4.66 & 3.37 & I \\
\hline
\end{tabular}

Note: CPI: $\left[\left(C_{25}+C_{27}+C_{29}+C_{31}+C_{33}\right) /\left(C_{26}+C_{28}+C_{30}+C_{32}+C_{34}\right)+\left(C_{25}+C_{27}+C_{29}+C_{31}+C_{33}\right) /\left(C_{24}\right.\right.$ $\left.\left.+C_{26}+C_{28}+C_{30}+C_{32}\right)\right] / 2$; OEP: $\left(C_{i}+6 C_{i+2}+C_{i+4}\right) /\left(4 C_{i+1}+4 C_{i+3}\right)$ or $\left(4 C_{i+1}+4 C_{i+3}\right) /\left(C_{i}+6 C_{i+2}+C_{i+4}\right)$ among which $\mathrm{i}+2$ is the maximum peak of n-alkanes with $\mathrm{i}$ corresponding to odd and even member, respectively; $\mathrm{Pr} / \mathrm{Ph}$ : pristane/phytane ratio; $\mathrm{Pr} / n \mathrm{C}_{17}$ : pristane/ $n \mathrm{C}_{17}$ ratio; $\mathrm{Ph} / n \mathrm{C}_{18}$ : phytane/ $n \mathrm{C}_{18}$ ratio; Dia/reg. Diasteranes/regular steranes; $C_{27} / C_{29} S: C_{27} / C_{29}$ sterane; $20 \mathrm{~S}: 20 \mathrm{~S} /(20 \mathrm{~S}+20 \mathrm{R})$ ratio for $\mathrm{C}_{29}-\alpha \alpha \alpha$ steranes; $\alpha \beta \beta$ : $\alpha \beta \beta /(\alpha \alpha \alpha+\alpha \beta \beta)$ ratio for $\mathrm{C}_{29}$ steranes; Ts $/(\mathrm{Ts}+\mathrm{Tm}): 18 \alpha(\mathrm{H})-/(18 \alpha(\mathrm{H})+17 \alpha(\mathrm{H}))$-trisnorhopane ratio; $\mathrm{G} / \mathrm{C}_{30} \mathrm{H}$ Gammacerane/ $\mathrm{C}_{30}$-hopane ratio; DBTs (\%): The amount of dibenzothiophenes in aromatics; "/": undetectable.

The hydrogen index (HI) of the analyzed source rocks ranged from $153.82 \mathrm{mg} / \mathrm{g}$ to $742.92 \mathrm{mg} / \mathrm{g}$, with an average of $468.38 \mathrm{mg} / \mathrm{g}$. The highest peak temperature $\left(\mathrm{T}_{\max }\right)$ ranged from $429{ }^{\circ} \mathrm{C}$ to $454.5{ }^{\circ} \mathrm{C}$, with an average of $440.56{ }^{\circ} \mathrm{C}$ (Figure 3, Table 1). The kerogen types of A1, B1-B3, and D1 in the analyzed samples were type I, C2 and D2 were type $\mathrm{II}_{\mathrm{A}}$ (I/II mixed type), and $\mathrm{C} 1$ was type $\mathrm{II}_{\mathrm{B}}$ (II/III mixed type). The result of the highest 
temperature peak $\left(\mathrm{T}_{\max }\right)$ converting to Ro shows that the thermal evolution of the sample was in the immature/low-mature stage, and the thermal evolution degree of A1, B1, and $\mathrm{B} 3$ was relatively low, with the converted Ro being less than $0.5 \%$ and the converted thermal evolution Ro of B2, C1, C2, D1, and D2 being $0.5-1.35 \%$. D1 and D2 had the highest degree of thermal evolution (Figure 3, Table 1).

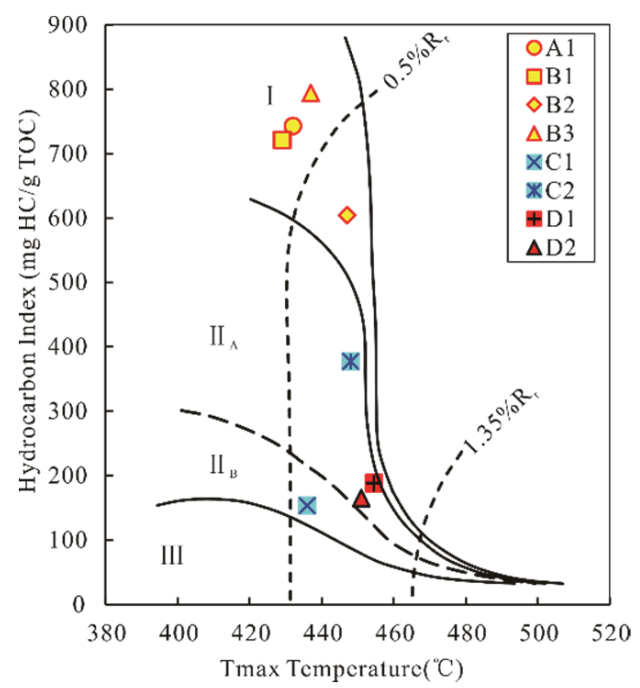

Figure 3. The relationship between the maximum pyrolysis temperature of the source rocks and the hydrogen index (HI) in the study area.

\subsubsection{Geochemical Characteristics of Soluble Organic Matter in Source Rock}

The distribution of soluble organic paraffins in the source rocks in the survey region is shown in Figure 4 and Table 1 . Normal-alkanes ( $n$-alkanes) are mainly distributed between $\mathrm{C}_{15}$ and $\mathrm{C}_{39}$. Most of them were monomodal, but several were bimodal (Figure 4 ), which may be related to the abundant steranes in the higher carbon numbers. The $\sum C_{21}-\sum C_{22+}$ ratios of n-alkanes in the source rocks were distributed from 0.39 to 1.54 , and the ratios of $\mathrm{C}_{21-22} / \mathrm{C}_{28-29}$ were from 0.28 to 0.85 (Table 1 ), reflecting both the terrestrial and aquatic organic matter contributions. Different degrees of odd-even predominance (OEP) and phytane dominance were detected for $n$-alkanes in the source rocks (Figure 4). Most of the samples have even carbon dominance, and some samples (A1, B1, and C2) of $\mathrm{C}_{23}-\mathrm{C}_{27}$ showed odd carbon advantage (Figure 4), indicating that their biogenic composition is complex. The carbon preference indices (CPI) and odd/even predominance (OEP) of the source rocks were from 0.76 to 1.06 and 0.72 to 1.12 , respectively, and the ratios of pristane/phytane (Pr/Ph) were from 0.07 to 0.52 , respectively (Table 1), indicating a strong reduction of the original sedimentary environment. In paraffins, different degrees of $n \mathrm{C}_{37}$ dominance were detected (Figure 4 ), which is consistent with the phenomenon of paraffins in saline lacustrine hydrocarbons that was observed by previous researchers. The abnormality of $n \mathrm{C}_{37}$ abundance may be related to its special source input, which is derived from methyl or ethyl ketones with 37 carbon bonds and two or three unsaturated bonds $[25,26]$. These ketones are mainly synthesized by algae. The development and survival of such algae are closely related to the environmental temperature. The $n C_{37}$ may indicate that the sedimentary environment is strongly reducing. The even carbon number advantage of $C_{20}-C_{26}$ is also the result of the reduction of oxygenated compounds [27-29]. In addition, $\beta$-carotene was detected in some samples (Figure 4), which is a manifestation of the strong reducing sedimentary environment and a higher salinity of the sedimentary water body. 


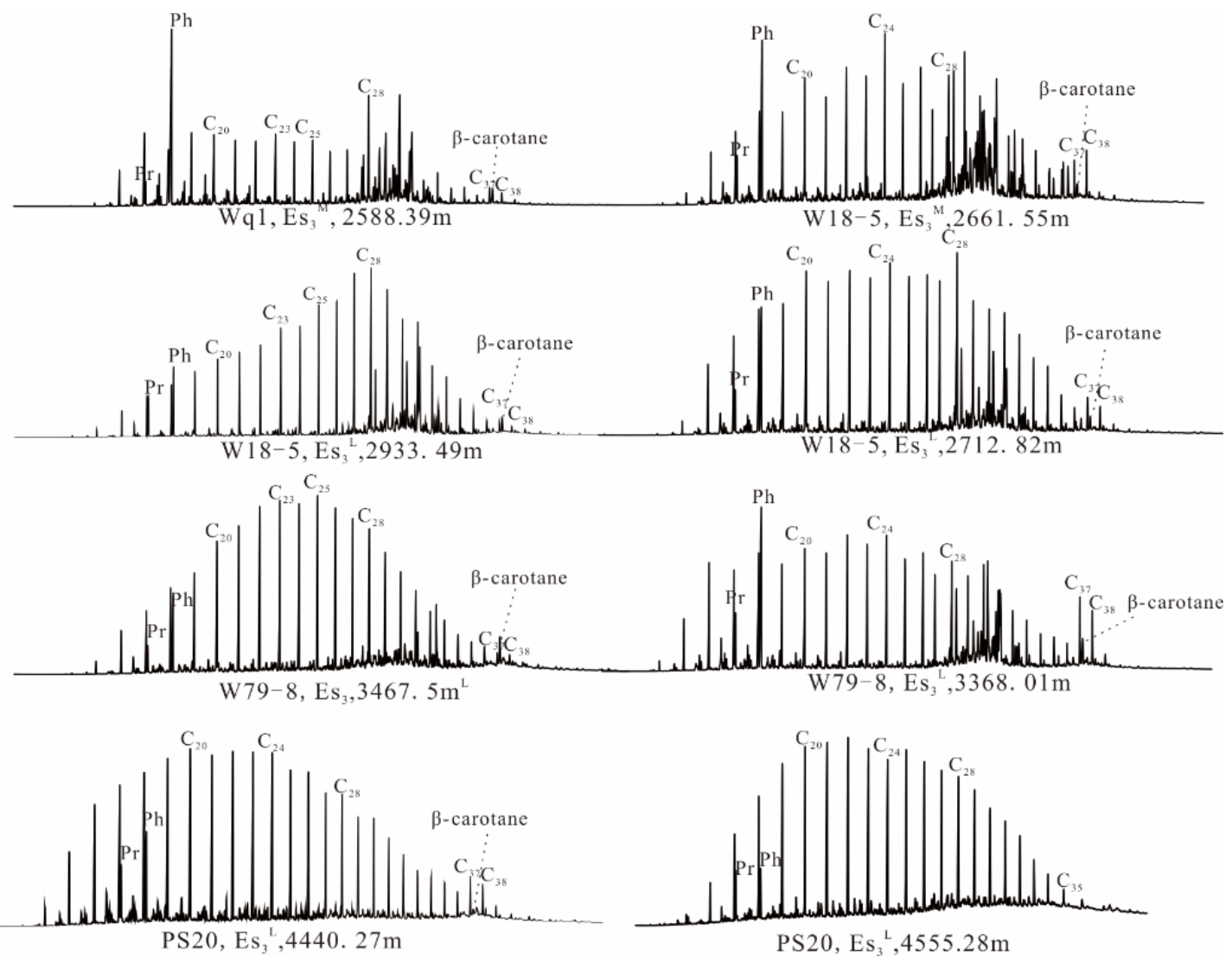

Figure 4. A diagram of the total ions of paraffins from source rocks in the study area.

Abundant steroids and terpenoids were detected in the source rocks (Figure 5). The steranes were mainly $\mathrm{C}_{27}-\mathrm{C}_{29}$ regular steranes. Diasteranes series and low molecular weight pregnane series were developed in the source rocks (Figure 5 left). The regular steranes $C_{27}-C_{29}$ in the analyzed samples showed an irregular V-shaped distribution (Figure 5 left). The ratios of $\mathrm{C}_{27-29}$ diasteranes/regular sterane in the source rock ranged from 0.08 to 1.2; and the ratios of $\mathrm{C}_{27} / \mathrm{C}_{29}$ sterane ranged from 0.51 to 1.96 , most of which were less than 1 (Figure 5, Table 1), reflecting that the parent sources were lower aquatic organisms that weremixed with higher plant sources. As the burial depth increased, the content of diasteranes increased significantly, and the degree of regular sterane isomerization became greater (Figure 5, left). The ratios of $\mathrm{C}_{29}$ regular steranes/diasteraness of the source rocks were distributed from 0.08 to 0.82 . The ratios of isomerization parameter $\mathrm{C}_{29} \alpha \alpha \alpha 20 \mathrm{~S} /(\mathrm{S}$ $+\mathrm{R})$ and $\mathrm{C}_{29}$ sterane iso $\alpha \beta \beta /(\alpha \alpha \alpha+\alpha \beta \beta)$ were from 0.17 to 0.57 and 0.22 to 0.58 , respectively (Table 1), indicating that the samples are distributed in immature/low-mature and mature stages [30-32]. The main terpenoids were pentacyclic triterpenes, followed by tricyclic terpenes, and $\mathrm{C}_{24}$ tetracyclic terpenes (Figure 5 right). Their relative abundance varies with maturity (Figure 5 right). In the later diagenesis stage, $\mathrm{Ts} /(\mathrm{Ts}+\mathrm{Tm})$ is often employed to reflect the maturity of hydrocarbons because $\mathrm{Ts}\left(\mathrm{C}_{28} 18 \alpha\right.$-trinorhopane) has stronger thermal stability than $\mathrm{Tm}\left(\mathrm{C}_{27} 17 \alpha\right.$-trinorhopane) [30]. The $\mathrm{Ts} /(\mathrm{Ts}+\mathrm{Tm})$ ratios of the source rocks in the study area were from 0.18 to 0.51 , and the ratio rises with the increase in burial depth (Table 1, Figure 5), which is consistent with the results of sterane isomerization parameters. Gammaceranes are significantly developed in the source rocks (Figure 5 right). The ratios of gammacerane $/ C_{30}$ hopanes were from 0.24 to 3.14 . The ratios of $C_{35}$ hopane $/ C_{34}$ hopane were from 0.62 to 1.54 (Table 1 ), reflecting that its organic matter originated from the original depositional environment with varying degrees of strong reduction [33-35]. In addition, abundant dibenzothiophene compounds were detected in aromatic hydrocarbons, with a relative abundance distribution of $2.89-35.34 \%$ (Table 1 ), 
which generally indicates that the original sedimentary organic matter of the study area came from a strong reduction depositional environment [36].

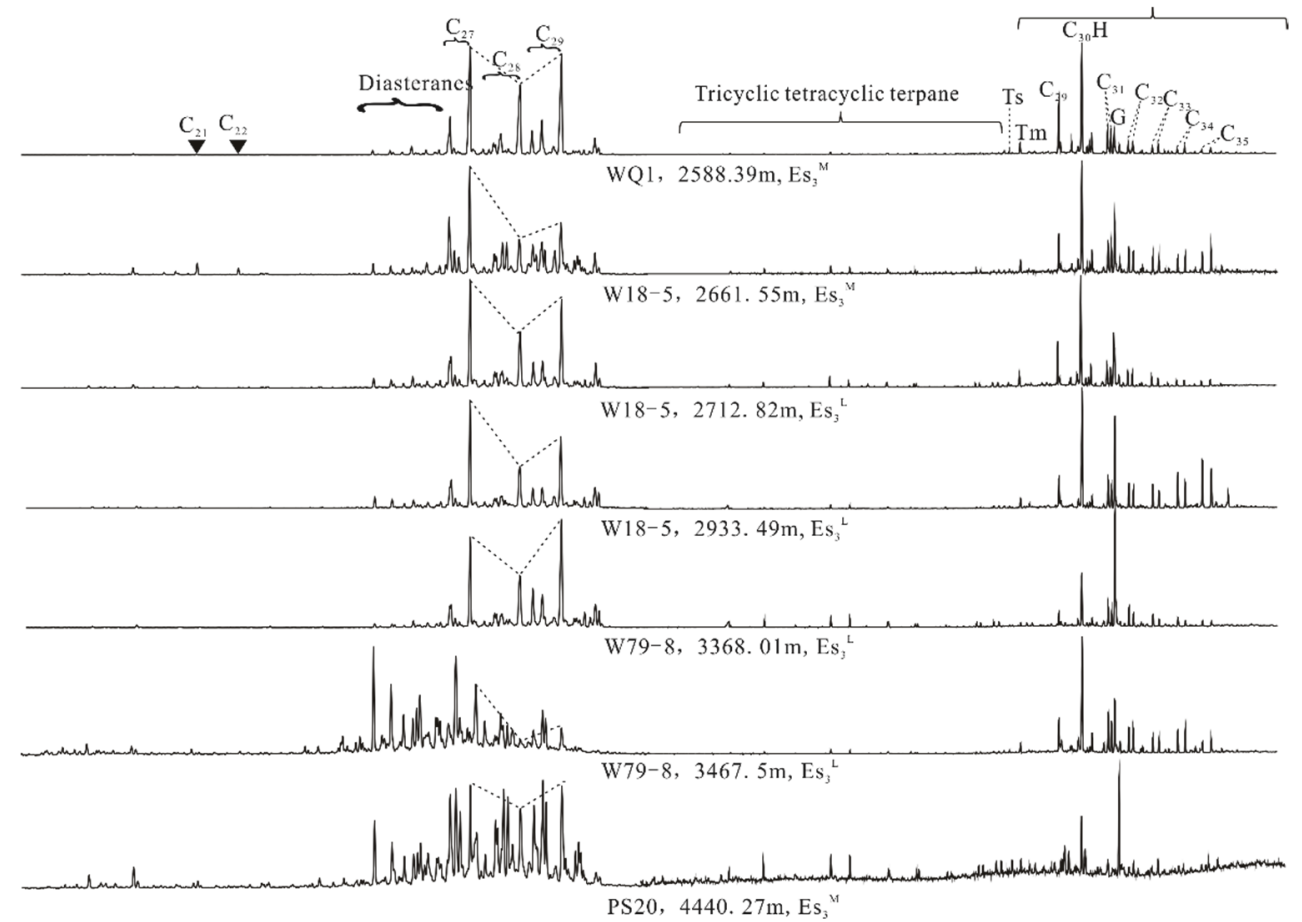

Figure 5. Mass chromatograms of $m / z 217$ and $m / z 191$ of the source rocks in the Dongpu Depression.

\subsection{Characteristics of NSO Compounds Revealed by FT-ICR MS}

\subsubsection{General Chemical Composition of Nitrogen and Oxygen Groups}

The negative ion ESI FT-ICR MS can detect acidic and non-basic nitrogen and oxygen heteroatom compounds [36]. A total of twelve species of heteroatom compounds were identified by negative ion ESI high-resolution mass spectrometry in the source rocks in the Dongpu Depression: $\mathrm{N}_{1}, \mathrm{~N}_{1} \mathrm{O}_{1}, \mathrm{~N}_{1} \mathrm{O}_{2}, \mathrm{~N}_{1} \mathrm{O}_{3}, \mathrm{~N}_{1} \mathrm{~S}_{1}, \mathrm{~N}_{1} \mathrm{~S}_{2}, \mathrm{~N}_{2} \mathrm{O}_{1}, \mathrm{O}_{1}, \mathrm{O}_{2}, \mathrm{O}_{3}, \mathrm{O}_{3} \mathrm{~S}_{1}$, and $\mathrm{O}_{4}$ (Figure 6). The types of heteroatom compounds were mainly $\mathrm{O}_{2}$ (except Well PS20), and their relative abundance distribution ranged from 24.39 to $60.16 \%$ (average $42.65 \%$ ), followed by $\mathrm{O}_{3}$ and $\mathrm{N}_{1}$ (Figure 6, Table 2). The relative abundance of $\mathrm{O}_{3}$ in the source rocks was $8.39-28.35 \%$ (average $16.52 \%$ ). The relative abundance of $\mathrm{N}_{1}$ types in the source rocks was widely distributed, and the abundance of $\mathrm{N}_{1}$ types was $0.85-44.24 \%$ (Figure 6, Table 2). The abundance of $\mathrm{N}_{1} \mathrm{O}_{1}$ and $\mathrm{O}_{4}$ was low. The relative abundance of $\mathrm{N}_{1} \mathrm{O}_{1}$ was $8.73 \%$ on average, and that of $\mathrm{O}_{4}$ was $6.66 \%$ on average. The abundance of other types of compounds was usually lower than 5\% (Table 2). Among the source rocks, Well PS 20 had the highest $\mathrm{N}_{1}$ abundance, followed by $\mathrm{O}_{2}$ and $\mathrm{N}_{1} \mathrm{O}_{1}$ (Figure 6, Table 2), which may be related to their high maturity. Nitrogen-containing compounds are very sensitive to the degree of thermal evolution, and the increase in thermal maturity will lead to significant enrichment of nitrogen-containing compounds $\left(\mathrm{N}_{1}, \mathrm{~N}_{1} \mathrm{O}_{1}\right)$ [37].

\subsubsection{Composition and Distribution of $\mathrm{N}_{1}$ Class}

Pyrrole nitrogen-containing compounds and their homologues are common in geological bodies [38,39]. The distribution of $\mathrm{N}_{1}$ compounds in the source rocks is shown in Figure 7 with different maturities. In the immature/low-mature stage (Figure $7 \mathrm{a}-\mathrm{c}$ ), the DBE of $\mathrm{N}_{1}$ compounds was mainly distributed in 9-18, with the DBE of 9 and 12 as the dominance (Figure 7a,b). The DBE of 9 and 12 are carzaoles and benzocarbazole classes, respectively. They were highly abundant in the shale rocks and have a wide distribution of carbon numbers, ranging from 18 to 42 , with $C_{24}$ and $C_{25}$ as the main peaks (Figure 7c). The compounds with DBE $=15$ were relatively low in abundance, with a narrow distribution of 
carbon numbers from 21 to 37 and $C_{25}$ as the main peak (Figure 7c). In the middle-maturity stage, the DBE of $\mathrm{N}_{1}$ compounds was distributed between 9 and 25 with 12 and 15 as the principal peaks (Figure $7 \mathrm{e}, \mathrm{f}$ ). The carbon number distribution of $\mathrm{N}_{1}$ compounds in the middle-maturity stage was narrower, ranging from 20 to 41 , with $C_{23}$ as the major peak (Figure $7 \mathrm{~d}, \mathrm{f})$.

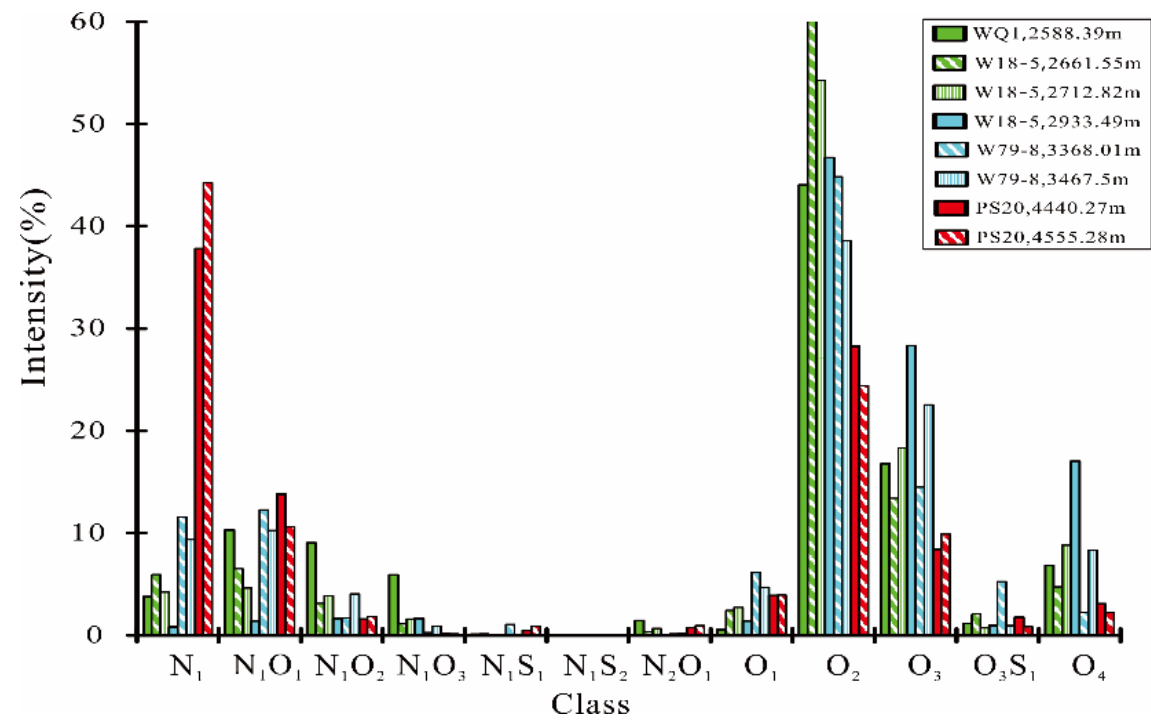

Figure 6. Distribution of the mudstone compound types in the Dongpu Depression as determined by negative ion high resolution mass spectrometry.

Table 2. The basic parameters of the source rock and oil sands extracts that were analyzed by negative-ion ESI FT-ICR MS.

\begin{tabular}{|c|c|c|c|c|c|c|c|c|}
\hline Well & WQ1 & W18-5 & W18-5 & W18-5 & W79-8 & W79-8 & PS20 & PS20 \\
\hline Depth (m) & 2588.39 & 2661.55 & 2712.82 & 2933.49 & 3368.01 & 3467.5 & 4440.27 & 4555.28 \\
\hline Strata & $\mathrm{Es}_{3}{ }^{\mathrm{M}}$ & $\mathrm{Es}_{3}{ }^{\mathrm{M}}$ & $\mathrm{Es}_{3}{ }^{\mathrm{L}}$ & $\mathrm{Es}_{3}{ }^{\mathrm{L}}$ & $\mathrm{Es}_{3}{ }^{\mathrm{L}}$ & $\mathrm{Es}_{3} \mathrm{~L}$ & $\mathrm{Es}_{3}{ }^{\mathrm{M}}$ & $\mathrm{Es}_{3}{ }^{\mathrm{L}}$ \\
\hline Lab. No. & A1 & B1 & B2 & B3 & C1 & $\mathrm{C} 2$ & D1 & D2 \\
\hline $\mathrm{N}_{1}$ & 3.77 & 11.53 & 5.94 & 4.23 & 0.85 & 9.38 & 44.24 & 37.80 \\
\hline $\mathrm{N}_{1} \mathrm{O}_{1}$ & 10.31 & 12.29 & 6.52 & 4.61 & 1.39 & 10.26 & 10.63 & 13.81 \\
\hline $\mathrm{N}_{1} \mathrm{O}_{2}$ & 9.05 & 1.66 & 3.13 & 3.90 & 1.62 & 4.04 & 1.82 & 1.59 \\
\hline $\mathrm{N}_{1} \mathrm{O}_{3}$ & 5.90 & 0.27 & 1.12 & 1.58 & 1.62 & 0.91 & 0.15 & 0.18 \\
\hline $\mathrm{N}_{1} \mathrm{~S}_{1}$ & 0.10 & 1.08 & 0.14 & 0.12 & 0.05 & 0.13 & 0.92 & 0.48 \\
\hline $\mathrm{N}_{1} \mathrm{~S}_{2}$ & 0.04 & 0.06 & 0.03 & 0.06 & 0.04 & 0.03 & 0.02 & 0.00 \\
\hline $\mathrm{N}_{2} \mathrm{O}_{1}$ & 1.42 & 0.16 & 0.30 & 0.69 & 0.00 & 0.19 & 0.97 & 0.77 \\
\hline $\mathrm{O}_{1}$ & 0.57 & 6.13 & 2.44 & 2.74 & 1.39 & 4.71 & 3.93 & 3.91 \\
\hline $\mathrm{O}_{2}$ & 44.05 & 44.84 & 60.15 & 54.27 & 46.71 & 38.55 & 24.39 & 28.23 \\
\hline $\mathrm{O}_{3}$ & 16.80 & 14.47 & 13.40 & 18.29 & 28.35 & 22.55 & 9.89 & 8.39 \\
\hline $\mathrm{O}_{3} \mathrm{~S}_{1}$ & 1.15 & 5.25 & 2.08 & 0.72 & 0.97 & 0.95 & 0.82 & 1.76 \\
\hline $\mathrm{O}_{4}$ & 6.84 & 2.25 & 4.75 & 8.79 & 17.01 & 8.32 & 2.23 & 3.07 \\
\hline $\mathrm{DBE}_{9}-\mathrm{N}_{1}(\%)$ & 34.53 & 43.50 & 26.28 & 21.30 & 0.00 & 18.92 & 4.06 & 2.07 \\
\hline $\mathrm{DBE}_{12}-\mathrm{N}_{1}$ & 46.08 & 40.74 & 44.06 & 42.85 & 8.12 & 35.81 & 21.18 & 16.57 \\
\hline $\mathrm{DBE}_{15}-\mathrm{N}_{1}(\%)$ & 19.39 & 15.76 & 29.66 & 35.86 & 91.88 & 45.27 & 74.76 & 81.36 \\
\hline $\mathrm{DBE}_{5}-\mathrm{O}_{2}(\%)$ & 98.81 & 88.68 & 86.79 & 77.33 & 80.18 & 63.97 & 49.75 & 34.68 \\
\hline $\mathrm{DBE}_{13}-\mathrm{O}_{2}(\%)$ & 0.80 & 8.62 & 8.40 & 14.70 & 11.13 & 20.83 & 28.14 & 36.42 \\
\hline $\mathrm{DBE}_{14}-\mathrm{O}_{2}(\%)$ & 0.39 & 2.70 & 4.81 & 7.97 & 8.68 & 15.20 & 22.11 & 28.91 \\
\hline $\mathrm{DBE}_{18-25} / \mathrm{DBE}_{9-18}-\mathrm{N}_{1}$ & 0.04 & 0.03 & 0.07 & 0.09 & 0.36 & 0.34 & 1.11 & 0.95 \\
\hline $\mathrm{DBE}_{12-20} / \mathrm{DBE}_{5-12}-\mathrm{O}_{2}$ & 0.02 & 0.10 & 0.11 & 0.15 & 0.18 & 0.24 & 0.63 & 0.64 \\
\hline $\mathrm{DBE}_{16-23} / \mathrm{DBE}_{9-18}-\mathrm{N}_{1} \mathrm{O}_{1}$ & 0.06 & 0.07 & 0.18 & 0.21 & 0.61 & 0.43 & 1.37 & 1.26 \\
\hline $\mathrm{O}_{2} / \mathrm{O}_{1}$ & 77.27 & 7.31 & 24.67 & 19.80 & 33.55 & 8.19 & 6.20 & 7.22 \\
\hline $\mathrm{N}_{1} / \mathrm{N}_{1} \mathrm{O}_{1}$ & 0.37 & 0.94 & 0.91 & 0.92 & 0.61 & 0.91 & 4.16 & 2.74 \\
\hline
\end{tabular}

Note: A: DBE $-\mathrm{N}_{1}(\%) ; \mathrm{B}_{\mathrm{DBE}} \mathrm{DB}_{12}(\%)$; C: DBE $15-\mathrm{N}_{1}(\%) ; \mathrm{D}: \mathrm{DBE}_{5}-\mathrm{O}_{2}(\%) ; \mathrm{E}: \mathrm{DBE}_{13}-\mathrm{O}_{2}(\%) ; \mathrm{F}: \mathrm{DBE}_{14}-\mathrm{O}_{2}(\%)$; G: $\mathrm{DBE}_{18-25} / \mathrm{DBE}_{9-18}-\mathrm{N}_{1} ; \mathrm{H}: \mathrm{DBE}_{12-20} / \mathrm{DBE}_{5-12}-\mathrm{O}_{2} ; \mathrm{I}_{\mathrm{DBE}} \mathrm{DB}_{16-23} / \mathrm{DBE}_{9-18}-\mathrm{N}_{1} \mathrm{O}_{1} ; \mathrm{J}: \mathrm{O}_{2} / \mathrm{O}_{1} ; \mathrm{K}: \mathrm{N}_{1} / \mathrm{N}_{1} \mathrm{O}$. 

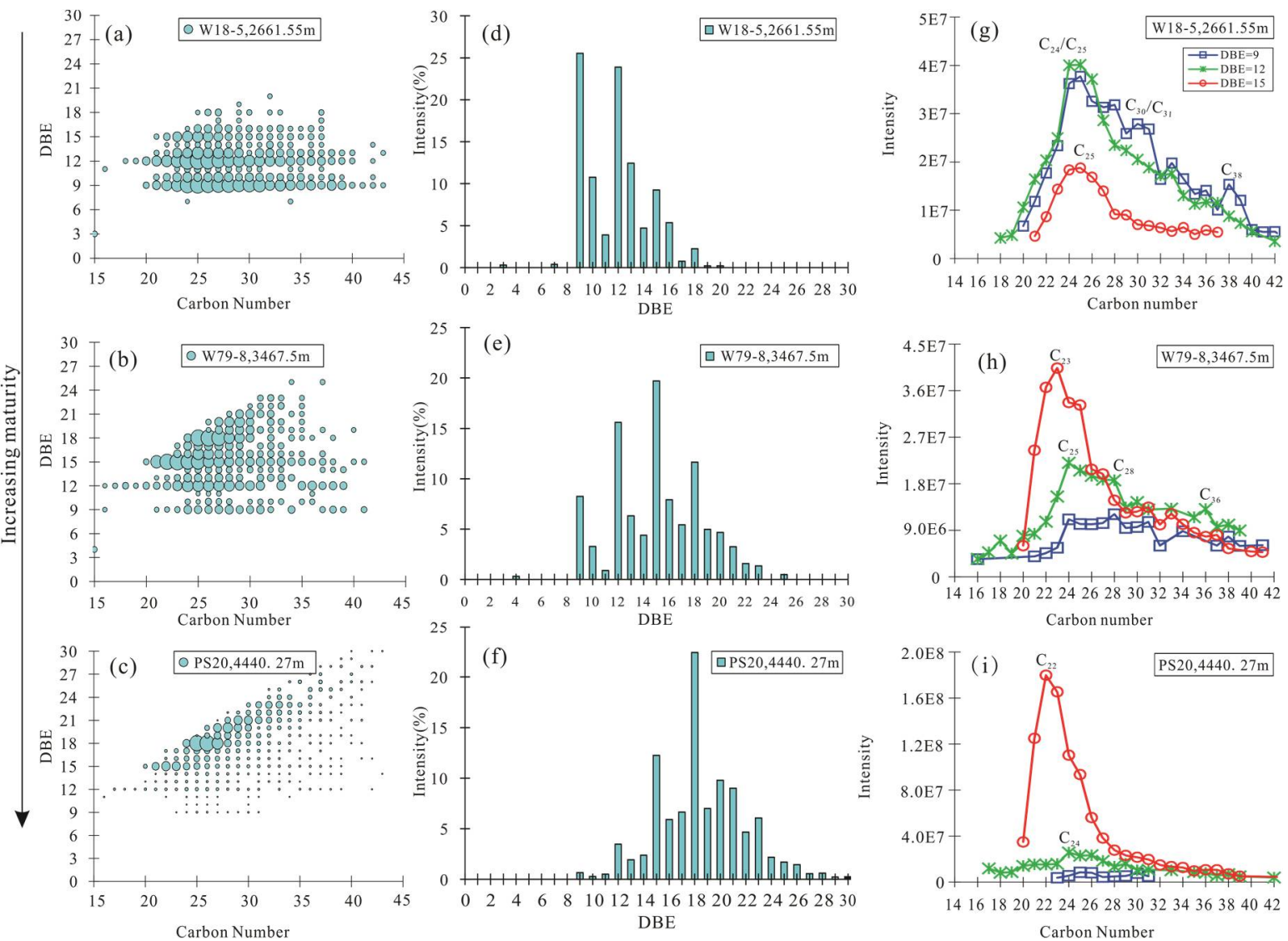

Figure 7. The relationship between the carbon number and DBE and its intensity $(\mathbf{a}-\mathbf{c})$, relative abundance of different DBEs (d-f), and carbon number and abundance distribution of DBE $=9,12$, and 15 (g-i) of $\mathrm{N}_{1}$ type with different maturities that was detected by negative ion ESI FT-ICR MS.

However, the distribution of $\mathrm{N}_{1}$ compounds was significantly different from the first two types in the mature samples (Figure $7 \mathrm{~g}-\mathrm{i}$ ). The DBE compounds were rich and distributed between 12 and 26 , and the carbon number distribution range was the narrowest, from 20 to 38, of which DBE = 18 had the highest abundance, followed by DBE $=15$ and $\mathrm{DBE}=20-23$ compounds (Figure 7g-i). The abundance of low DBE compounds decreased rapidly. The carbon number of DBE $=15$ was distributed from 20 to 42 , and the main peak carbon was forwarded to $C_{22}$. The abundance of $\mathrm{DBE}=9$ and 12 was extremely low, with $\mathrm{C}_{24}$ as the main peak carbon, and the carbon numbers ranged from 23 to 32 and 17 to 42 , respectively (Figure $7 \mathrm{~g}, \mathrm{i}$ ).

\subsubsection{Composition and Distribution of $\mathrm{O}_{2}$ Class}

The distribution of $\mathrm{O}_{2}$ compounds in the source rocks in the Dongpu Depression as detected by negative ion ESI FT-ICR MS is shown in Figure 8. The carbon numbers ranged from 12 to 50, most of which are between 15 and 35. The DBE value ranged from 0 to 22 and generally ranged from 1 to 18 (Figure 8). With an increase in the maturity, the carbon number was much narrower (Figure 8). Previous research has shown that DBE $=1$ in the $\mathrm{O}_{2}$ species are fat acids (Figure 8). DBE $=5$ and 6 are naphthenic acids with special biological skeleton structures, among which $\mathrm{C}_{27}-\mathrm{C}_{30}$ in $\mathrm{DBE}=5$ may be steranoics acid or secohopanic acids, $\mathrm{C}_{28}-\mathrm{C}_{36}$ in DBE $=6$ are hopanoic acids. Species with DBE values of 2-7 are naphthenic acids with 1-6 naphthenic rings [40]. These compounds mostly appear in immature and low-mature oils. Naphthenic acids with special biological skeletons with different abundances were also observed in the immature source rocks (Figure 8).

The $\mathrm{O}_{2}$ compounds in the source rock are affected by thermal maturation more obviously. In the low-maturity stage (Figure 8 ), the DBE values of the $\mathrm{O}_{2}$ species were mainly 
ranged from 1 to 14 and the carbon number, between 12 and 45 . Fatty acids $(\mathrm{DBE}=1)$ are most dominant, followed by DBE $=2-13$. More abundant hopane acid and sterane acid with special biological skeletons were observed (Figure 8). At the mature stage (Figure 8), the DBE value is mainly distributed between 1 and 17 , with a higher abundance in DBE $=5-17$. At a higher maturity stage (Figure 8), the $\mathrm{O}_{2}$ compounds are enriched in high DBE compounds, ranging from 0 to 20, and the carbon chain is much shorter with a carbon number that ranges from 15 to 35 (Figure 8).

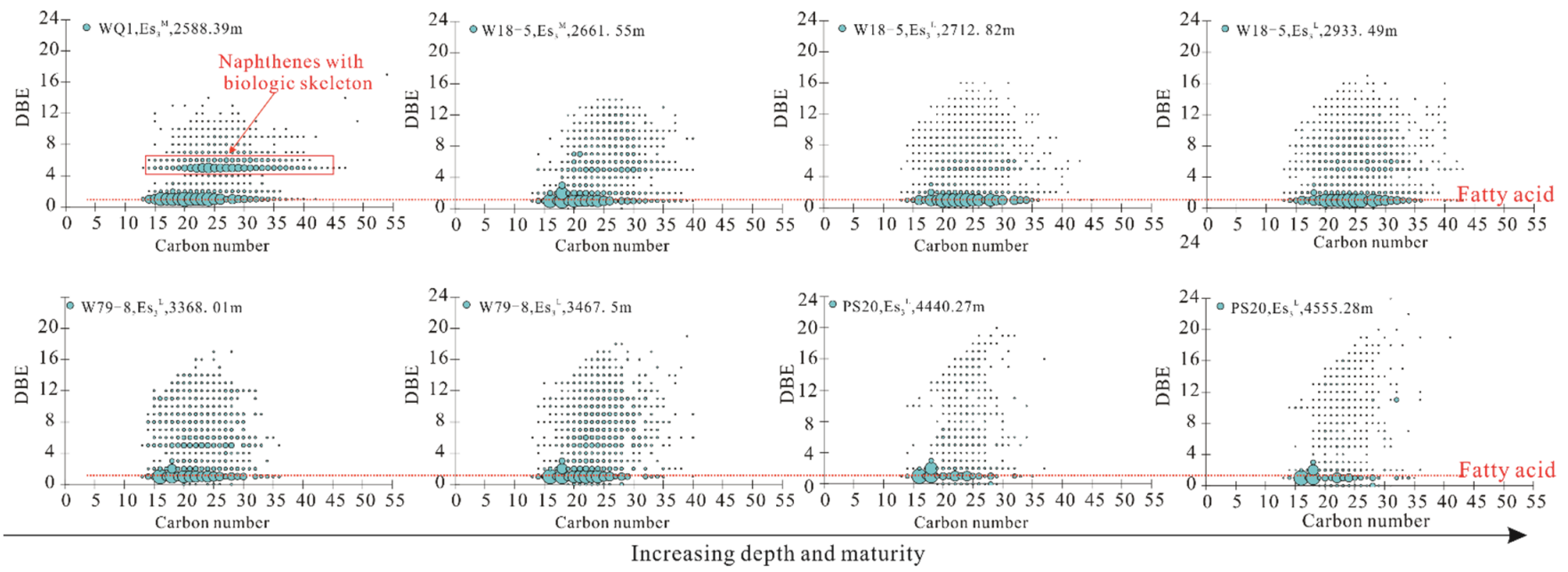

Figure 8. Relationship between the carbon numbers and DBE values of the analyzed samples detected by negative ion ESI FT-ICR MS with increasing depth and maturity. Class of DBE $=1$ of $\mathrm{O}_{2}$ (fatty acids) are detected in the analyzed samples.

\subsubsection{Composition and Distribution of $\mathrm{O}_{3}$ Class}

The abundance of $\mathrm{O}_{3}$ compounds in shale rocks is second only to $\mathrm{O}_{2}$ compounds in most of the samples (Figure 6, Table 2). The carbon numbers of the $\mathrm{O}_{3}$ compounds are distributed between 12 and 42, with most of them between 15 and 35 (Figure 9a-c). The DBE values were distributed between 1 and 20, with most of them between 1 and 16 (Figure 9a-f). Similar to the other NO compounds that are mentioned above, as the burial depth increases, the carbon number range narrows, while the DBE value distribution range becomes larger with higher DBE compounds enriched (Figure 9a-f). $\mathrm{O}_{3}$ species have the advantage of $\mathrm{C}_{22}$ and $\mathrm{C}_{24}$ at $\mathrm{DBE}=1$ (Figure $9 \mathrm{~g}-\mathrm{i}$ ). $\mathrm{DBE}=1-3$ of $\mathrm{O}_{3}$ compounds may be hydroxycarboxylic acid compounds [41]. The monohydric alcohol compounds under the negative ion ESI condition and the protic solvent molecules in the solvent, such as methanol, ethanol, water, and $\mathrm{CO}_{2}$ structure, adduct to form $\mathrm{O}_{3}$ and $\mathrm{O}_{4}$ compounds, and the possible formation mechanism of $\mathrm{O}_{3}$ compounds is that the monohydric alcohols directly interact with $\mathrm{CO}_{2}$. The $\mathrm{O}_{4}$ compounds were synthesized from $\mathrm{O}_{3}$ compounds and protic solvent molecules [42].

The high abundance of $\mathrm{C}_{22}$ mono alcohol of $\mathrm{O}_{3}$ species in the source rocks in the Dongpu Depression may come mostly from phytoplankton. Studies have shown that the carbon number distribution of normal monohydric alcohols in low-mature oil generally ranges from $C_{10}$ to $C_{35}$, with varying degrees of even/odd dominance [43], and long-chain normal monohydric alcohols are related to their parent sources and can be used to predict their biogenic composition. For example, the phytoplankton in the Baltic Sea is mainly cyanobacteria, and the main component of normal monohydric alcohols is $\mathrm{C}_{22}$ [44]. A high content of $\mathrm{C}_{22}$ normal mono alcohol was also detected in the algae-rich Green River shale [45]. A high abundance of $\mathrm{nC}_{22}$ mono alcohol was also observed in the source rocks of the Lower Shahejie Formation in the Raoyang Depression, which are rich in special algae of early generation [46]. The contribution of phytoplankton input is also in accordance with the biomarker results. 

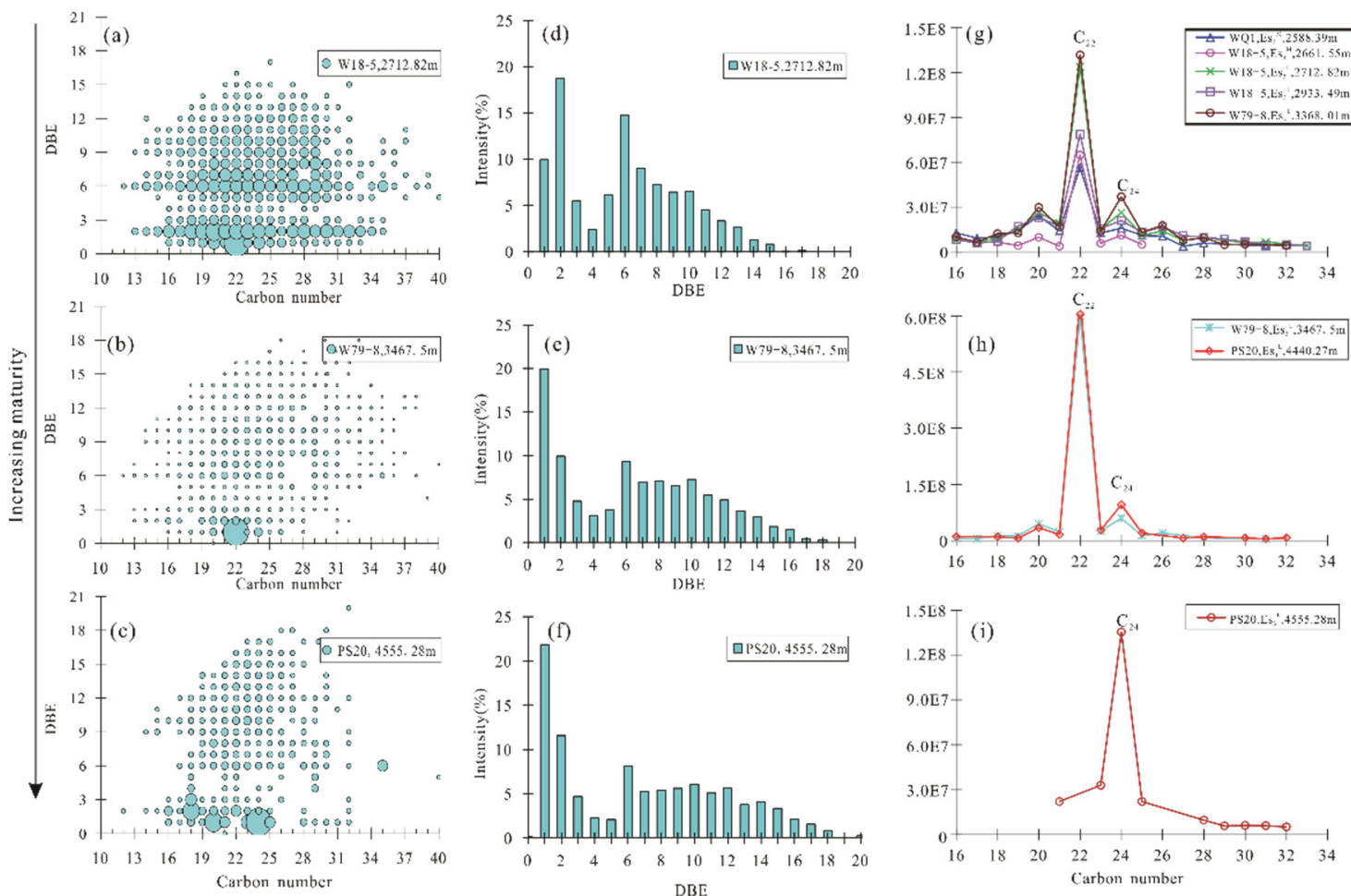

Figure 9. The relationship between the carbon number and $\operatorname{DBE}(\mathbf{a}-\mathbf{c})$, the relative abundance of different $\operatorname{DBEs}(\mathbf{d}-\mathbf{f})$, and the carbon number and abundance distribution of DBE $=1,2$, and 6 (g-i) of $\mathrm{O}_{3}$ type that were observed by negative ion ESI FT-ICR MS in the source rocks of the Dongpu Depression.

\section{Discussion}

\subsection{Maturity Evaluation}

NSO heteroatomic compounds that were analyzed by high resolution mass spectrometry were utilized to identify the maturity of crude oil and source rock in previous studies. It was reported that $S_{1}$ compounds in $\mathrm{DBE}_{1,3,6} / \mathrm{DBE}_{9}, \mathrm{C}_{10-19} / \mathrm{C}_{20-50}, \mathrm{DBE}_{9}, \mathrm{~S}_{2} / \mathrm{S}_{1}$, and other parameters have a good correlation with conventional maturity indicators and thus can be used as such $[47,48]$. $\mathrm{C}_{16-20} / \mathrm{C}_{21-50}-\mathrm{DBE}_{12}-\mathrm{N}_{1}, \mathrm{C}_{20-24} / \mathrm{C}_{25-50}-\mathrm{DBE}_{15}-\mathrm{N}_{1}$, and $\mathrm{C}_{11-15} / \mathrm{C}_{16-27^{-}}$ $\mathrm{DBE}_{4}-\mathrm{O}_{1}$ that were detected by high resolution mass spectrometry in negative ion mode have good correlations with biomarker maturity indicators and can be used for the thermal evolution of hydrocarbons in the mature to high-maturity stages [49], but for low-mature hydrocarbons in the saline lacustrine facies, the influence of their nitrogen and oxygen heteroatom compounds on thermal maturity and their geochemical significance remains to be explored.

The DBE and carbon numbers in the $\mathrm{N}_{1}$ compounds are in line with the basic principles of thermochemical kinetics. According to Hughey et al. [10,40], polarized changes are found in hydrocarbons during thermal evolution. As the maturity increases, the relative abundance of the $\mathrm{N}_{1}$ compounds increases; the aromatization intensifies, and the long carbon chain broken into short chains (Figure 7). The $\mathrm{O}_{2}$ species in the source rock show a similar trend to the $\mathrm{N}_{1}$ species. As the maturity increases, high DBE compounds are enriched, and the carbon chain becomes shorter (Figure 8). Studies have shown that the long-chain fatty acids in immature kerogen are thermally cracked during the maturation process to produce more of the shorter fatty acids [50,51]. The decarboxylation activity of long-chain fatty acids and the thermal evolution process will cause "condensation" [52], which will affect the distribution of the fatty acids.

In general, as the degree of maturity increases, the relative amount of oxygen-containing compounds decreases, the relative abundance of nitrogen-containing heteroatom compounds increases, and the highly condensed and aromatized polar molecular nuclei in- 
crease with a decrease in alkyl and saturated chain length $[53,54]$. It is also observed that the $\mathrm{N}_{1}$ species and $\mathrm{O}_{2}$ species are influenced by maturity (Figures 7-9).

According to the ternary diagram of the DBE relationships between the different $\mathrm{N}_{1}$ compounds and $\mathrm{O}_{2}$ compounds, with the increase of maturity, the $\mathrm{N}_{1}$ compounds shift to 12 and 15 with higher DBEs (Figure 10). Similarly, the $\mathrm{O}_{2}$ compounds shift from a low DBE value of 5 to higher DBE values of 13 and 14 with increasing maturity (Figure 10), showing that thermal evolution controls the degree of condensation in heteroatom compounds, leading to increases in their aromatization and condensation. As the maturity increases, a large number of macromolecular structures in the kerogen structure are released. High DBE compounds may be formed from alkyl side chain cyclization and the aromatic compounds of low DBE compounds $[53,54]$.

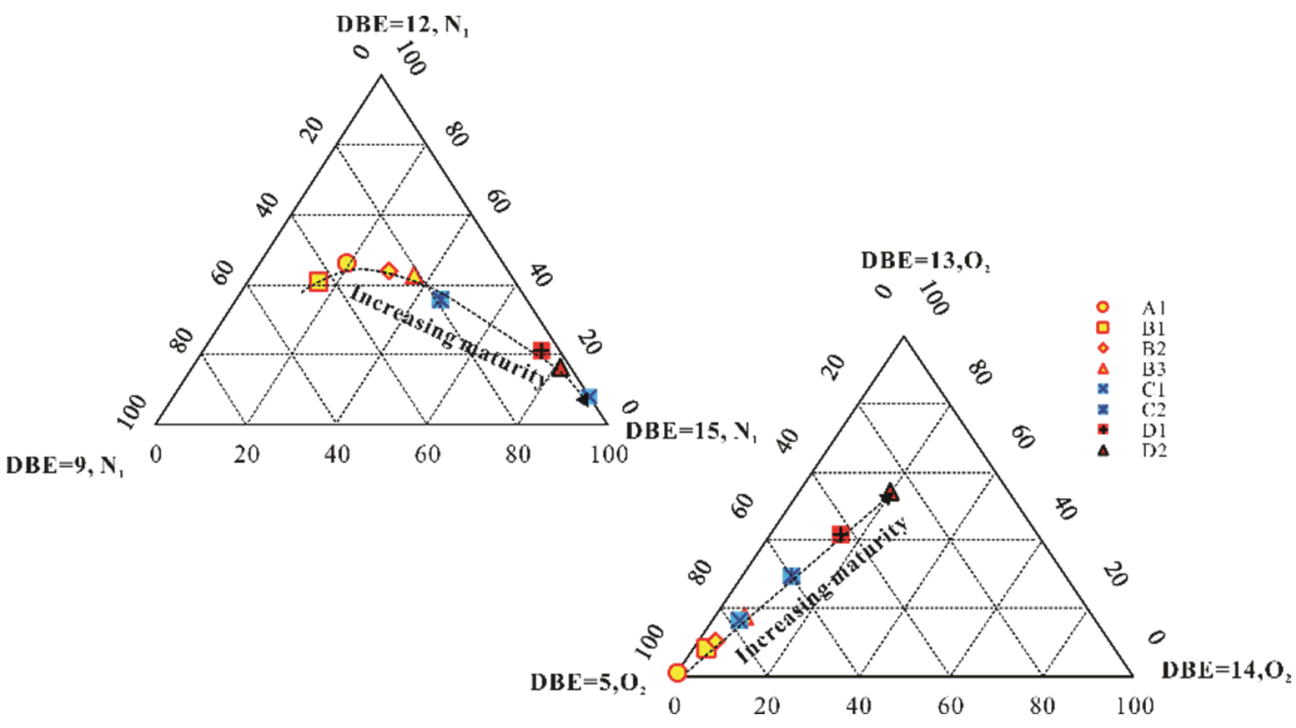

Figure 10. Ternary diagram of $\mathrm{DBE}=9,12$, and 15 for $\mathrm{N}_{1}$ and $\mathrm{DBE}=5,13$, and 14 for $\mathrm{O}_{2}$.

The ratios of $C_{29}$ sterane isomerization parameter ratio $(20 S /(20 S+20 R)$ and $\beta \beta /(\beta \beta+\alpha \alpha)$, terpenoids $\mathrm{Ts} /(\mathrm{Ts}+\mathrm{Tm})$, and diasterane/regular sterane are widely used to evaluate the maturity of source rock, but they have a certain scope of application, especially for sterane isomerization parameters [30]. It was found that the ratios of $\mathrm{DBE}_{18-25} / \mathrm{DBE}_{9-18^{-}}$ $\mathrm{N}_{1}$ and $\mathrm{DBE}_{12-20} / \mathrm{DBE}_{5-12}-\mathrm{O}_{2}$ are related to the source rock biomarker maturity parameter $\mathrm{C}_{29} 20 \mathrm{~S} /(20 \mathrm{~S}+20 \mathrm{R}), \alpha \beta \beta /(\alpha \alpha \alpha+\alpha \beta \beta), \mathrm{Ts} /(\mathrm{Ts}+\mathrm{Tm})$, diasterane/regular sterane. The related coefficient $(r)$ between $\mathrm{DBE}_{18-25} / \mathrm{DBE}_{9-18}-\mathrm{N}_{1}$ and conventional geochemical maturity parameters $C_{29}\left(20 S /(20 S+20 R), C_{29} \beta \beta /(\beta \beta+\alpha \alpha)\right.$, Ts $/(T s+T m)$, and diasterane/regular sterane are $0.81-0.90$ (Figure $11 \mathrm{a}-\mathrm{d}$ ). The related coefficient ${ }^{\circledR}$ between $\mathrm{DBE}_{12-20} / \mathrm{DBE}_{5-12}-\mathrm{O}_{2}$ and conventional geochemical maturity parameters $C_{29}\left(20 S /(20 S+20 R), C_{29} \beta \beta /(\beta \beta+\alpha \alpha)\right.$, $\mathrm{Ts} /(\mathrm{Ts}+\mathrm{Tm})$, and diasterane/regular sterane are 0.85-0.96 (Figure $11 \mathrm{e}-\mathrm{h})$. The above parameters can be used as auxiliary indicators for hydrocarbon evaluation in the lowmature and maturity stages.

\subsection{Origins of the Organic Matter}

The distribution of fatty acids is not only affected by thermal maturation but also by the type of maternal source; the distribution of fatty acids usually indicates a specific biological source. Through decarboxylation or reduction, normal fatty acids with corresponding carbon numbers are produced. The contribution of normal fatty acids to immature/low-mature hydrocarbons with high carbon number alkanes is quite obvious [55]. The distribution of fatty acid compounds with $\mathrm{DBE}=1$ in $\mathrm{O}_{2}$ type in source rocks is similar to that of normal alkanes (Figures 4 and 12). The normal alkanes of soluble organic matter in the source rocks of the Dongpu Depression have $C_{24}$ as the main peak, and the carbon number is mainly distributed between $C_{20}$ and $C_{28}$, which may have a 
biogenic relationship with the fatty acid compounds in $\mathrm{O}_{2}$. Previous studies have shown that long-chain normal fatty acids with high carbon numbers, such as $n \mathrm{C}_{26}$ and $n \mathrm{C}_{28}$ as the main peaks, have strong even carbon advantages and are mainly derived from the surface wax of terrestrial higher plants, while low carbon numbers, such as $n \mathrm{C}_{16}$ and $n \mathrm{C}_{18}$, are related to algae or aquatic organisms [56].
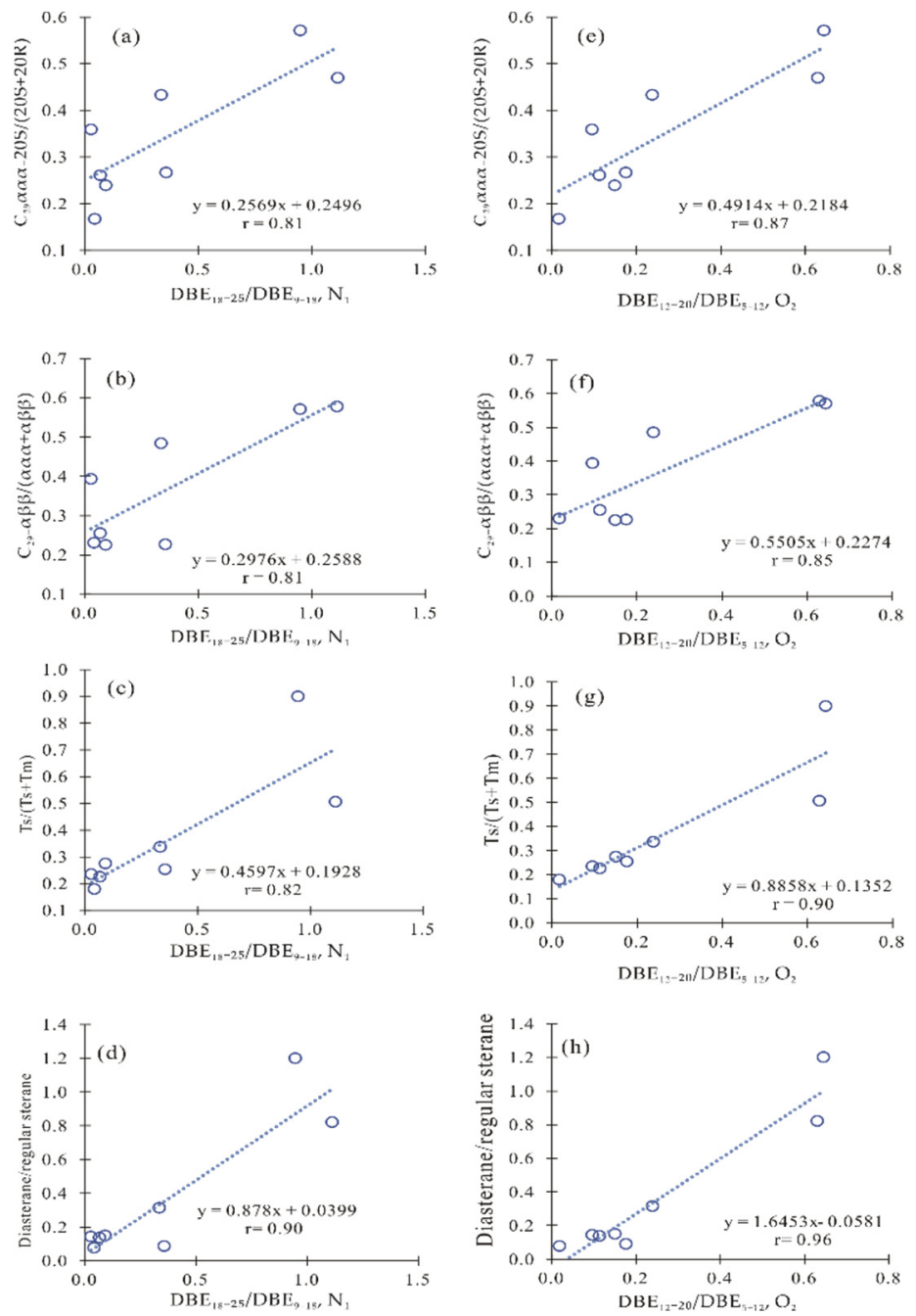

Figure 11. Relationship between the $\mathrm{N}_{1}-$ and $\mathrm{O}_{2}-$, ratios $\left(\mathrm{DBE}_{18-25} / \mathrm{DBE}_{9-18}, \mathrm{~N}_{1}\right.$; $\mathrm{DBE}_{12-20} / \mathrm{DBE}_{5-12}, \mathrm{O}_{2}$ ) that were revealed by FT-IC MS and conventional maturity parameters. (a-d) show the relationship between $\mathrm{DBE}_{18-25} / \mathrm{DBE}_{9-18} \mathrm{~N}_{1}$ and $\mathrm{C}_{29} \alpha \alpha \alpha-20 \mathrm{~S} /(20 \mathrm{~S}+20 \mathrm{R}), \mathrm{C}_{29} \alpha \beta \beta / \alpha \alpha \alpha$ $+\alpha \beta \beta$, Ts $/(\mathrm{Ts}+\mathrm{Tm})$ and Diasterane/regular sterane, respectively. (e-h) show the relationship between $\mathrm{DBE}_{12-20} / \mathrm{DBE}_{5-12}, \mathrm{O}_{2}$ and $\mathrm{C}_{29} \alpha \alpha \alpha-20 \mathrm{~S} /(20 \mathrm{~S}+20 \mathrm{R}), \mathrm{C}_{29} \alpha \beta \beta / \alpha \alpha \alpha+\alpha \beta \beta$, Ts / (Ts + Tm $)$ and Diasterane/regular sterane, respectively.

Normal fatty acids are unimodal and their parent material may be mainly lower aquatic organisms, such as algae, while the bimodal type indicates that their parent source has dual biogenic inputs from aquatic organisms, such as algae and terrestrial higher plants [57]. On the whole, the $\mathrm{O}_{2}$ compounds in the shallow source rocks in the Dongpu Depression are basically unimodal with $\mathrm{C}_{20}-\mathrm{C}_{24}$ as the main peak, followed by $\mathrm{C}_{28}$ (Figure 12), indicating that their source may be mainly algae and other aquatic organisms that are mixed with some higher plant input. The result is consistent with the previous conclusions on paraffin and biomarker parameters [30]. However, some samples have the advantages of $\mathrm{C}_{16}$ and $\mathrm{C}_{18}$. In addition to the higher abundance in the shallow layer, the abundance of $C_{16}$ and $C_{18}$ in the deep layer is also higher, which may be related to pollution [9]. In 
general, fatty acids are mainly present in the non-hydrocarbon and asphaltene components of asphalt in the form of ester bonds. They are mostly monobasic fatty acids and have more high-carbon long-chain fatty acids. In the low-evolution stage, asphalt fatty acids are formed $[41,58]$. There are more high-carbon long-chain alkanes in the hydrocarbons. When the degree of evolution increases, the low-carbon kerogen fatty acids eliminate the network constraints and enter the asphalt where they are transformed into hydrocarbons, causing the increase of low-carbon alkanes in the mature hydrocarbons and the decrease of high carbon number alkanes [42,43]. The alkanes that are produced by the early fatty acids of low-mature hydrocarbons are mainly from asphalt fatty acids, which have odd carbon advantages, while the alkanes that are produced by mature oil-generating rocks contain more alkanes from kerogen non-basic fatty acids and lose the odd carbon advantage [42,43]. The odd carbon advantage in $n$-alkanes in some source rocks in the Dongpu Depression is probably the result of early fatty acid conversion.
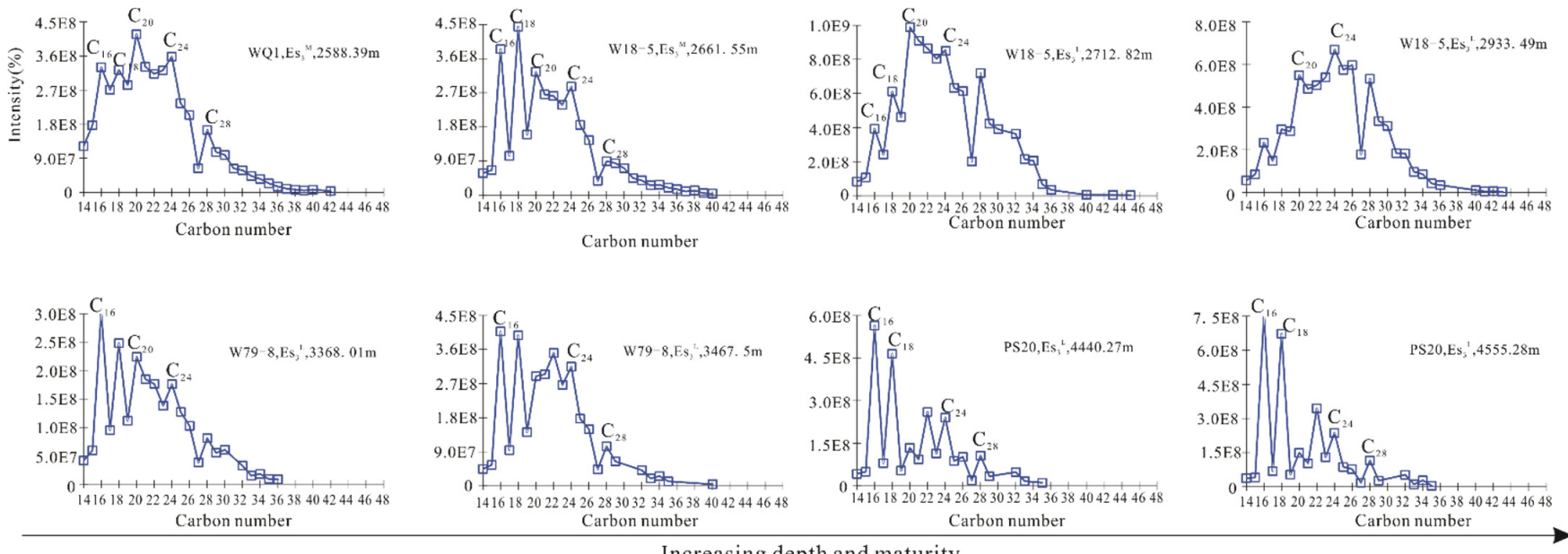

Increasing depth and maturity

Figure 12. The intensity of analyzed samples with different carbon numbers for $\mathrm{DBE}=1$ in $\mathrm{O}_{2}$ species by negative ion ESI FT-ICR MS.

\subsection{Paleoenvironment Identification}

The organic matter depositional environment is significant to understand the origin of petroleum. Biomarker parameters from chromatographic mass spectrometry are often used to distinguish different depositional environments, such as the pristane/phytane value $(\mathrm{Pr} / \mathrm{Ph})$ and the gammacerane $/ \mathrm{C}_{30}$ hopane ratio [30]. Studies on the hydrocarbons of terrestrial freshwater lacustrine facies (Lango Sag, Liaohe Basin, Maoming, and Subei Basin) and saline/brackish water transition facies (Songliao Basin, Qianjiang Basin, and Jizhou Sag) have been carried out by Fu et al. [59]. They showed that phytane is abnormally high and that there are high ratios of gammacerane and homohopane in the saline lacustrine facies [59]. These parameters can distinguish freshwater/saltwater lacustrine mud shale. as the brackish water is a transitional phase, the ratios of $\mathrm{Pr} / \mathrm{Ph}$ and gammacerane $/ C_{30}$ hopanes are between the saline lacustrine facies and the freshwater lacustrine facies (Figure 13a). The composition and distribution characteristics of nitrogen and oxygen heteroatom compounds in different depositional environments are obviously different as reflected by FT-ICR MS. NSO heteroatom compounds in the saline lacustrine facies in the Dongpu Depression, the freshwater lacustrine facies in the Nanpu Sag, and the brackish to saline lacustrine facies in the Biyang Sag have been compared. It was observed that the source rocks in the saline lacustrine facies are rich in $\mathrm{O}_{2}$ classes and have less $\mathrm{N}_{1}$ than those of the freshwater lacustrine facies. It was also found that the source rocks in the saline lacustrine facies of the Dongpu Depression have a higher $\mathrm{O}_{2} / \mathrm{O}_{1}$ ratio, generally greater than 10, in the strongly reducing sedimentary environment of the saline lacustrine facies, while the ratios in the freshwater/brackish transitional facies are low, most of which are less than 10 (Figure $13 \mathrm{~b}$, Table 2). The abundance of $\mathrm{N}_{1} / \mathrm{N}_{1} \mathrm{O}_{1}$ in the source rocks of the 
saline lacustrine facies in the Dongpu Depression is generally low, usually lower than 2 (Figure 13b, Table 2). This result is consistent with the results of the conventional GC-MS depositional environment parameter indicators. The nitrogen and oxygen compounds that were revealed by FT-ICR MS have a promising application in distinguishing among different depositional environments.
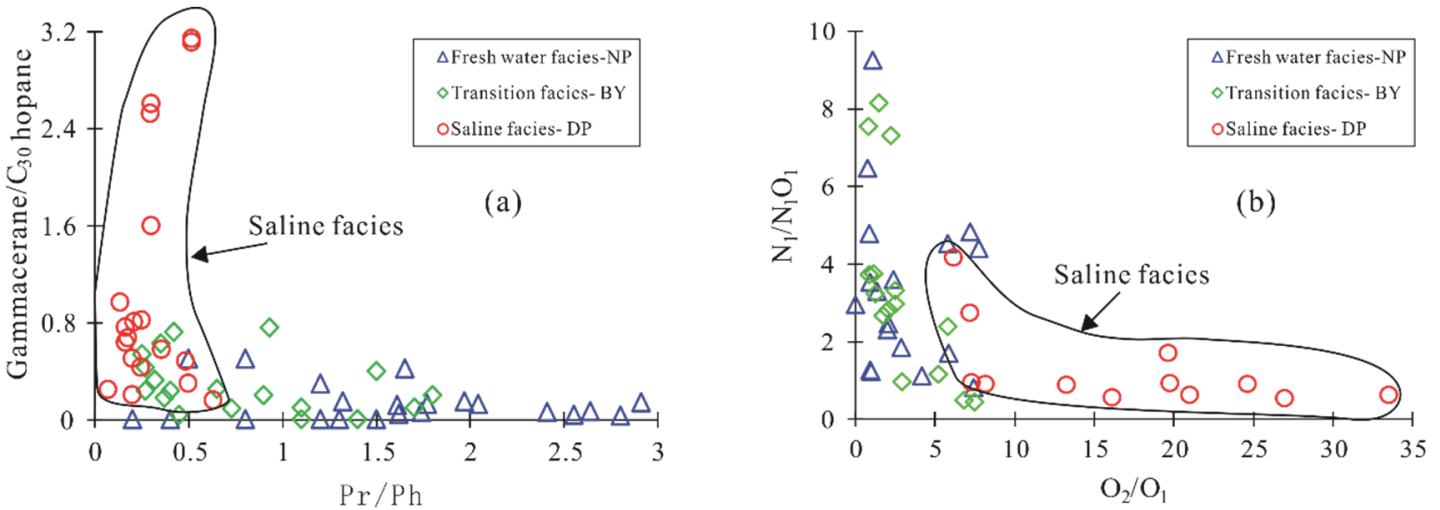

Figure 13. Parameters from (a) conventional GC-MS and (b) high resolution mass spectrometry to identify different sedimentary environments.

\section{Conclusions}

The negative ion mode ESI FT-ICR MS revealed the distribution types of heteroatomic compounds in the immature/low-mature to mature source rocks in the northern saline lacustrine facies of the Dongpu Depression. They are $\mathrm{N}_{1}, \mathrm{~N}_{1} \mathrm{O}_{1}, \mathrm{~N}_{1} \mathrm{O}_{2}, \mathrm{~N}_{1} \mathrm{O}_{3}, \mathrm{~N}_{1} \mathrm{~S}_{1}, \mathrm{~N}_{1} \mathrm{~S}_{2}$, $\mathrm{N}_{2} \mathrm{O}_{1}, \mathrm{O}_{1}, \mathrm{O}_{2}, \mathrm{O}_{3}, \mathrm{O}_{3} \mathrm{~S}_{1}$, and $\mathrm{O}_{4}$. Of these compounds, most are of the $\mathrm{O}_{2}$ type, followed by $\mathrm{O}_{3}$ and $\mathrm{N}_{1}$, while $\mathrm{N}_{1} \mathrm{O}_{1}$ and $\mathrm{O}_{4}$ are relatively low in abundance.

$\mathrm{N}_{1}$ compounds are dominated by alkylcarbazole compounds, such as DBE $=9,12$, 15 , and 18. $\mathrm{O}_{2}$ compounds are dominated by fatty acid compounds with $\mathrm{DBE}=1$, and compounds with $\mathrm{DBE}=5$ and 6(mainly sterane acids and hopanoic acids) were detected in the middle and shallow layers. The distribution of fatty acid compounds and alkanes in $\mathrm{O}_{2}$ may have a parental relationship, with $\mathrm{C}_{20}$ to $\mathrm{C}_{24}$ as the main peak, followed by $\mathrm{C}_{28} . \mathrm{O}_{3}$ compounds may be produced by monohydric alcohols. The composition and distribution characteristics of oxygenated compounds in hydrocarbons have great potential in predicting the original parent material. The $\mathrm{N}_{1}, \mathrm{O}_{2}$, and $\mathrm{N}_{1} \mathrm{O}_{1}$ compounds are affected by their maturity and they often run to polarization with enhanced DBE species and shorter carbon chain as the maturity increases.

Combined with conventional geochemical data, compounds of $\mathrm{DBE}_{18-25} / \mathrm{DBE}_{9-18}-\mathrm{N}_{1}$ and $\mathrm{DBE}_{12-20} / \mathrm{DBE}_{5-12}-\mathrm{O}_{2}$ are very consistent with maturity parameters $\mathrm{C}_{29}$ sterane isomerization $20 \mathrm{~S} /(20 \mathrm{~S}+20 \mathrm{R}), \alpha \beta \beta /(\alpha \alpha \alpha+\alpha \beta \beta)$, Ts $/(\mathrm{Ts}+\mathrm{Tm})$, and diasterane/regular sterane. The correlation coefficient index $(r)$ of $\mathrm{DBE}_{18-25} / \mathrm{DBE}_{9-18}-\mathrm{N}_{1}$ and $\mathrm{DBE}_{12-20} / \mathrm{DBE}_{5-12}-\mathrm{O}_{2}$ range from 0.81 to 0.90 and 0.85 to 0.96 . They can be used as an auxiliary index for the evaluation of source rocks in the low-maturity to mature stages.

Compared with the freshwater sedimentary environment, the original sedimentary environment with the strong reduction of saline lacustrine facies is more enriched in $\mathrm{O}_{2}$ (acids) and less enriched in $\mathrm{N}_{1}$. The saline lacustrine facies has a higher $\mathrm{O}_{2} / \mathrm{O}_{1}$ ratio, usually $>10$, but the $\mathrm{N}_{1} / \mathrm{N}_{1} \mathrm{O}_{1}$ abundance is generally low, usually lower than 2 , which is consistent with the sedimentary environment that was classified by conventional geochemical parameters. It was concluded that the distribution characteristics of heteroatom compounds that were revealed by negative ion ESI FT-ICR MS shed light on identifying the depositional environments of different source rocks.

Author Contributions: Conceived and designed the experiments: H.J. and S.L., sampling: T.X. and H.Z.; wrote the paper: H.J.; and modified the manuscript: S.L. and X.P. All authors have read and agreed to the published version of the manuscript. 
Funding: This work is supported by the National Natural Science Foundation of China (42073064), Natural Science Foundation of Guangdong Province, China (20201515110555), and Projects of Talents Recruitment of GDUPT (519017).

Institutional Review Board Statement: Not applicable.

Informed Consent Statement: Not applicable.

Data Availability Statement: The data that were used to support the findings of this study are available from the corresponding author upon request.

Acknowledgments: The authors would like to thank Quan-Shi for his assistance in organic geochemical analysis. The authors would also like to thank anonymous reviewers for their constructive comments and suggestions.

Conflicts of Interest: The authors declare no conflict of interest.

\section{References}

1. Zachariah, S.B.; Petri, U.K.; Vahur, O.; Ville, A. Hydrogen solubility of shale oil containing polar phenolic compounds. Ind. Eng. Chem. Res. 2017, 56, 8738-8747.

2. Zhang, L.; Lu, X.; Liu, X.; Li, Q.; Cheng, Y.; Hou, Q.; Cai, J. Distribution and mobility of crude oil-brine in clay mesopores: Insights from molecular dynamics simulations. Langmuir 2019, 35, 14818-14832. [CrossRef] [PubMed]

3. Zhang, J.; Cao, J.; Xia, L.; Xiang, B.; Li, E. Investigating biological nitrogen cycling in lacustrine systems by FT-ICR-MS analysis of nitrogen-containing compounds in petroleum. Palaeogeogr. Palaeoclimatol. Palaeoecol. 2020, 556, 109887. [CrossRef]

4. $\quad$ Bai, L.; Liu, B.; Yang, J.; Tian, S.; Wang, B.; Huang, S. Differences in hydrocarbon composition of shale oils in different phase states from the Qingshankou Formation, Songliao Basin, as determined from fluorescence experiments. Front. Earth Sci. 2021, 15, 438-456. [CrossRef]

5. Li, M.W.; Liu, P.; Jiang, Q.G.; Li, Z.M.; Cao, T.T. Effect of thermal maturation on the composition of polar organic compounds in the Eocene lacustrine shales of the Bohai Bay Basin in eastern China as revealed by FT-ICR-MS analysis of hydrous pyrolysates. In Proceedings of the AAPG Annual Conference and Exhibition, Houston, TX, USA, 6-9 April 2014.

6. Eseme, E.; Littke, R.; Agyingi, C.M. Geochemical characterization of a cretaceous black shale from the Mamfe Basin, Cameroon. Pet. Geosci. 2006, 12, 69-74. [CrossRef]

7. $\quad \mathrm{Fu}, \mathrm{X} . ;$ Jian, W.; Zeng, Y.; Li, Z.; Wang, Z. Geochemical and palynological investigation of the Shengli river marine oil shale (China): Implications for paleoenvironment and paleoclimate. Int. J. Coal Geol. 2009, 78, 217-224. [CrossRef]

8. Bastow, T.P.; Aarssen, B.; Alexander, R.; Kagi, R.I. Origins of alkylphenols in crude oils: Hydroxylation of alkylbenzenes. Org. Geochem. 2005, 36, 991-1001. [CrossRef]

9. Liao, Y.; Shi, Q.; Hsu, C.S.; Pan, Y.; Zhang, Y. Distribution of acids and nitrogen-containing compounds in biodegraded oils of the Liaohe Basin by negative ion ESI FT-ICR MS. Org. Geochem. 2012, 47, 51-65. [CrossRef]

10. Hughey, C.A.; Rodgers, R.P.; Marshall, A.G.; Walters, C.C.; Qian, K.; Mankiewicz, P. Acidic and neutral polar NSO compounds in Smackover oils of different thermal maturity revealed by electrospray high field Fourier transform ion cyclotron resonance mass spectrometry. Org. Geochem. 2004, 35, 863-880. [CrossRef]

11. Liu, P.; Li, M.; Jiang, Q.; Cao, T.; Sun, Y. Effect of secondary oil migration distance on composition of acidic NSO compounds in crude oils determined by negative-ion electrospray Fourier transform ion cyclotron resonance mass spectrometry. Org. Geochem. 2015, 78, 23-31. [CrossRef]

12. Tang, Y.; Wen, Z.; Dou, L.; Youde, X. Research on the direction of secondary migration of oil by making use of nitrogen compounds as tracers in the No. 6 area of the Melut Basin. Chin. J. Geochem. 2006, 25, 182-183. [CrossRef]

13. Zhang, L.C. Oil migration in the Lunnan region, Tarim basin, China based on the pyrrolic nitrogen compound distribution. J. Pet. Sci. Eng. 2004, 41, 123-134.

14. Wang, M.; Guo, Z.; Jiao, C.; Lu, S.; Li, J.; Xue, H.; Jijun, L.; Li, J.; Chen, G. Exploration progress and geochemical features of lacustrine shale oils in China. J. Pet. Sci. Eng. 2019, 178, 975-986. [CrossRef]

15. Hu, T.; Pang, X.; Jiang, F.; Wang, Q.; Zhang, C. Movable oil content evaluation of lacustrine organic-rich shales: Methods and a novel quantitative evaluation model. Earth-Sci. Rev. 2021, 214, 103545. [CrossRef]

16. Hu, T.; Pang, X.-Q.; Jiang, F.-J.; Wang, Q.-F.; Wu, G.-Y.; Liu, X.-H.; Jiang, S.; Li, C.-R.; Xu, T.-W.; Chen, Y.-Y. Key factors controlling shale oil enrichment in saline lacustrine rift basin: Implications from two shale oil wells in Dongpu depression, Bohai Bay Basin. Pet. Geosci. 2021, 18, 687-711. [CrossRef]

17. Wang, M.; Sherwood, N.; Li, Z.S.; Lu, S.F.; Wang, W.G.; Huang, A.H.; Lu, K. Shale oil occurring between salt intervals in the Dongpu Depression, Bohai Bay Basin, China. Int. J. Coal Geol. 2015, 152, 100-112. [CrossRef]

18. Ji, H.; Li, S.; Zhang, H.; Pang, X.; Zhou, Y.; Xiang, L. Molecular characterization of NSO compounds and paleoenvironment implication for saline lacustrine oil sands by positive-ion mass spectrometry coupled with Fourier-transform ion cyclotron resonance mass spectrometry. ACS Omega 2021, 6, 25680-25691. [CrossRef] [PubMed] 
19. Li, S.; Ji, H.; Wan, Z.; Pang, X.; Zhou, Y. Geochemical characteristics and factors controlling the deep lithologic reservoirs in Puwei Sag, Dongpu Depression-A case study of well PS20. J. Pet. Sci. Eng. 2021, 203, 108669. [CrossRef]

20. Jiang, Z.R.; Zuo, Y.H.; Yang, M.H.; Zhang, Y.X.; Zhou, Y.S. Source rocks evaluation of the Paleogene Shahejie 3 Formation in the Dongpu Depression, Bohai Bay Basin. Energy Explor. Exploit. 2019, 37, 394-411. [CrossRef]

21. Li, Y.; Zeng, X.; Cai, J.; Wang, X.; Mu, X.; Zhang, Y. Mudrocks lithofacies characteristics and North-South hydrocarbon generation difference of the Shahejie Formation in the Dongpu Sag. Minerals 2021, 11, 535. [CrossRef]

22. Shi, Q.; Zhao, S.; Xu, Z.; Chung, K.H.; Zhang, Y.; Xu, C. Distribution of acids and neutral nitrogen compounds in a Chinese crude oil and its fractions: Characterized by negative-ion electrospray ionization Fourier transform ion cyclotron resonance mass spectrometry. Energy Fuels 2010, 24, 4005-4011. [CrossRef]

23. Peters, K.E.; Cassa, M.R. Applied Source Rock Geochemistry. In The Petroleum System-From Source to Trap; Magoon, L.B., Dow, W.G., Eds.; American Association of Petroleum Geologists: Tulsa, OK, USA, 1994; Volume 60, pp. 93-111.

24. Hazra, B.; Dutta, S.; Kumar, S. TOC calculation of organic matter rich sediments using rock-eval pyrolysis: Critical consideration and insights. Int. J. Coal Geol. 2017, 169, 106-115. [CrossRef]

25. Koopmans, M.P.; Shaeffer-Reiss, C.; de Leeuw, J.W.; Lewan, M.D.; Maxwell, J.R.; Schaeffer, P.; Sinninghe, D.J.S. Sulfur and oxygen sequestration of $\mathrm{nC}_{37}$ and $\mathrm{nC}_{38}$ unsaturated ketones in an immature kerogen and the release of their carbon skeletons during early stages of thermal maturation. Geochim. Cosmochim. Acta 1997, 61, 2397-2408. [CrossRef]

26. Sampei, Y.; Inaba, T.; Suzuki, N. Abnormally abundant alkenone-derived $C_{37}$, and $C_{38} n$-alkanes in Miocene Onnagawa siliceous mudstones, northeast Japan. Org. Geochem. 2003, 34, 1247-1258. [CrossRef]

27. Zhang, Y.; Su, Y.; Liu, Z.; Chen, X.; Yu, J.; Di, X.; Jin, M. Long-chain branched/cyclic alkanes in recent sediment of Lake Fuxian and their environmental implications. Chin. Sci. Bull. 2014, 59, 1139-1150. [CrossRef]

28. Volkman, J.K.; Eglinton, G.; Corner, E.S.; Sargent, J.R. Novel unsaturated straight-chain $\mathrm{C}_{37}-\mathrm{C}_{39}$ methyl and ethyl ketones in marine sediments and a coccolithophore emiliania huxleyi. Phys. Chem. Earth 1980, 12, 219-227. [CrossRef]

29. Grice, K.; Schouten, S.; Peters, K.E.; Damsté, J.S. Molecular isotopic characterization of hydrocarbon biomarkers in PaleoceneEocene evaporitic, lacustrine source rocks from the Jianghan Basin, China. Org. Geochem. 1998, 29, 1745-1764. [CrossRef]

30. Peters, K.; Walters, C.; Moldowan, J. Biomarkers and Isotopes in Petroleum Systems and Earth History. In The Biomarker Guide; Cambridge University Press: Cambridge, UK, 2004; pp. 473-474.

31. Farrimond, P.; Taylor, A.; Telns, N. Biomarker maturity parameters: The role of generation and thermal degradation. Org. Geochem. 1998, 29, 1181-1197. [CrossRef]

32. Chen, Z.; Zha, M.; Jin, Q.; Ren, Y. Distribution of sterane maturity parameters in a lacustrine basin and their control factors: A case study from the Dongying Sag, East China. Pet. Sci. 2011, 8, 290-301. [CrossRef]

33. Damste, J.S.S.; Schouten, S.; Volkman, J.K. C-27-C-30 neohop-13(18)-Enes and their saturated and aromatic derivatives in sediments: Indicators for diagenesis and water column stratification. Geochim. Cosmochim. Acta 2014, 133, 402-421. [CrossRef]

34. Zhang, Z.; Li, C.; Cheng, M.; Algeo, T.J.; Jin, C.; Tang, F.; Huang, J. Evidence for highly complex redox conditions and strong water-column stratification in an early Cambrian Continental-Margin Sea. Geochem. Geophys. Geosyst. 2018, 19, 2397-2410. [CrossRef]

35. Wang, Y.P.; Zhan, X.; Gao, Y.; Xia, J.; Wang, S.; Zou, Y.R. Geochemical signatures and controlling factors of rearranged hopanes in source rocks and oils from representative Basins of China. ACS Omega 2020, 5, 30160-30167. [CrossRef] [PubMed]

36. Li, S.; Pang, X.; Shi, Q.; Zhang, B.; Zhang, H.; Pan, N.; Zhao, M. Origin of the unusually high dibenzothiophene concentrations in Lower Ordovician oils from the Tazhong Uplift, Tarim Basin, China. Pet. Sci. 2011, 8, 382-391. [CrossRef]

37. Li, M.; Yao, H.; Stasiuk, L.D.; Fowler, M.G.; Larter, S.R. Effect of maturity and petroleum expulsion on pyrrolic nitrogen compound yields and distributions in Duvernay formation petroleum source rocks in central Alberta, Canada. Org. Geochem. 1997, 26, 731-744. [CrossRef]

38. Snyder, L.R. Distribution of benzcarbazole isomers in petroleum as evidence for their biogenic origin. Nature 1965, $205,277$. [CrossRef]

39. Li, M.W.; Larter, S.R.; Stoddart, D.; Bjoroy, M. Liquid-chromatographic separation schemes for pyrrole and pyridine nitrogen aromatic heterocycle fractions from crude oils suitable for rapid characterization of geochemical samples. Anal. Chem. 1992, 64, 1337-1344. [CrossRef]

40. Hughey, C.A.; Rodgers, R.P.; Marshall, A.G.; Qian, K.; Robbins, W.K. Identification of acidic NSO compounds in crude oils of different geochemical origins by negative ion electrospray Fourier transform ion cyclotron resonance mass spectrometry. Org. Geochem. 2002, 33, 743-759. [CrossRef]

41. Hamerly, T.; Tripet, B.; Wurch, L.; Hettich, R.L.; Podar, M.; Bothner, B.; Copie, V. Characterization of fatty acids in Crenarchaeota by GC-MS and NMR. Archaea 2015, 2015, 472726. [CrossRef]

42. Zhe, L.; Zhang, Z.; Sun, Y.; Lao, Y.; Wu, W. Catalytic decarboxylations of fatty acids in immature oil source rocks. Sci. China Ser. D Earth Sci. 2003, 46, 1250-1260.

43. Zhang, Z.; Sun, Y.; Lao, Y.; Lin, W. Catalytic decarboxylation of fatty acid by iron-containing minerals in immature oil source rocks at low temperature. Chin. Sci. Bull. 1999, 44, 1523-1527. [CrossRef]

44. Warden, L.; Van, D.J.; Moros, M.; Damste, J.S. Sedimentary alkenone distributions reflect salinity changes in the Baltic Sea over the Holocene. Org. Geochem. 2016, 102, 30-44. [CrossRef]

45. Sever, J.; Parker, P.L. Fatty alcohols (normal and isoprenoid) in sediments. Science 1969, 164, 1052-1054. [CrossRef] [PubMed] 
46. Qin, J.Z.; Wang, J.; Xin, L.I.; Zhang, X.B. Study on the hydrocarbon-generating and pool-forming conditions of immature oil in the Raoyang Depression of the Bohaiwan Basin. Pet. Geol. Exp. 2003, 25, 566-572.

47. Li, S.; Amrani, A.; Pang, X.; Yang, H.; Said-Ahmad, W.; Zhang, B.; Pang, Q. Origin and quantitative source assessment of deep oils in the Tazhong uplift, Tarim Basin. Org. Geochem. 2015, 78, 1-22. [CrossRef]

48. Li, S.; Shi, Q.; Pang, X.; Zhang, B.; Zhang, H. Origin of the unusually high dibenzothiophene oils in Tazhong-4 oilfield of Tarim Basin and its implication in deep petroleum exploration. Org. Geochem. 2012, 48, 56-80. [CrossRef]

49. Wan, Z.; Li, S.; Pang, X.; Dong, Y.; Wang, Z.; Chen, X.; Meng, X.; Shi, Q. Characteristics and geochemical significance of heteroatom compounds in terrestrial oils by negative-ion electrospray Fourier transform ion cyclotron resonance mass spectrometry. Org. Geochem. 2017, 111, 34-55. [CrossRef]

50. Barrow, M.P.; Mcdonnell, L.A.; Feng, X.; Walker, J.; Derrick, P.J. Determination of the nature of naphthenic acids present in crude oils using Nanospray Fourier transform ion cyclotron resonance mass spectrometry: The continued battle against corrosion. Anal. Chem. 2003, 75, 860-866. [CrossRef]

51. Jaffe, R.; Gardinali, P.R. Generation and maturation of carboxylic acids in ancient sediments from the Maracaibo Basin, Venezuela. Org. Geochem. 1990, 16, 211-218. [CrossRef]

52. Zhu, C.; Zhao, H.; Wang, P.R.; Song, Y.T. Feature and evolution of NSO component in spiral algae-study on the formation mechanism of immature oil. J. Jianghan Pet. Inst. 1998, 20, 22-25.

53. Oldenburg, T.P.; Brown, M.; Bennett, B.; Larter, S.R. The impact of thermal maturity level on the composition of crude oils, assessed using ultra-high resolution mass spectrometry. Org. Geochem. 2014, 75, 151-168. [CrossRef]

54. Shimoyama, A.; Johns, W.D. Formation of alkanes from fatty acids in the presence of $\mathrm{CaCO}_{3}$. Geochim. Cosmochim. Acta 1972, 36, 87-91. [CrossRef]

55. Gillan, F.T.; Stoilov, I.L.; Thompson, J.E.; Hogg, R.W.; Wilkinson, C.R.; Djerassi, C. Fatty acids as biological markers for bacterial symbionts in sponges. Lipids 1988, 23, 1139-1145. [CrossRef] [PubMed]

56. Kennicutt, M.C.; Brooks, J.M. Unusual normal alkane distributions in offshore New Zealand sediments. Org. Geochem. 1990, 15, 193-197. [CrossRef]

57. Fang, J.; Wu, F.; Xiong, Y.; Li, F.; Du, X.; An, D.; Wang, L. Source characterization of sedimentary organic matter using molecular and stable carbon isotopic composition of n-alkanes and fatty acids in sediment core from Lake Dianchi, China. Sci. Total Environ. 2014, 473, 410-421. [CrossRef] [PubMed]

58. Grimalt, J.; Albaiges, J. Source and occurrence of $\mathrm{C}_{12}-\mathrm{C}_{22}$ n-alkane distributions with even carbon-number preference in sedimentary environments. Geochim. Cosmochim. Acta 1987, 51, 1379-1384. [CrossRef]

59. Fu, J.; Sheng, G.; Xu, J.; Eglinton, G.; Gowar, A.P.; Jia, R.; Peng, P.A. Application of biological markers in the assessment of paleoenvironments of Chinese non-marine sediments. Org. Geochem. 1990, 16, 769-779. 